Elroy Dimson

London Business School

Carolina Minio-Paluello

Goldman Sachs

\title{
The Closed-End Fund Discount
}

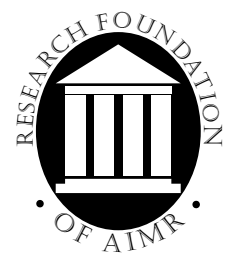

The Research Foundation of AIMR ${ }^{\mathrm{TM}}$ 


\section{Research Foundation Publications}

Active Currency Management

by Murali Ramaswami

Anomalies and Efficient Portfolio Formation by S.P. Kothari and Jay Shanken

Common Determinants of Liquidity and Trading by Tarun Chordia, Richard Roll, and Avanidhar Subrahmanyam

Company Performance and Measures of Value Added

by Pamela P. Peterson, CFA, and

David R. Peterson

Controlling Misfit Risk in Multiple-Manager Investment Programs

by Jeffery V. Bailey, CFA, and David E. Tierney

Corporate Governance and Firm Performance

by Jonathan M. Karpoff, M. Wayne Marr, Jr., and

Morris G. Danielson

Country Risk in Global Financial Management by Claude B. Erb, CFA, Campbell R. Harvey, and

Tadas E. Viskanta

Country, Sector, and Company Factors in

Global Equity Portfolios

by Peter J.B. Hopkins and C. Hayes Miller, CFA

Currency Management: Concepts and Practices

by Roger G. Clarke and Mark P. Kritzman, CFA

Earnings: Measurement, Disclosure, and the

Impact on Equity Valuation

by D. Eric Hirst and Patrick E. Hopkins

Economic Foundations of Capital Market Returns by Brian D. Singer, CFA, and

Kevin Terhaar, CFA

Emerging Stock Markets: Risk, Return, and Performance

by Christopher B. Barry, John W. Peavy III,

CFA, and Mauricio Rodriguez

Franchise Value and the Price/Earnings Ratio by Martin L. Leibowitz and Stanley Kogelman

The Franchise Value Approach to the Leveraged Company

by Martin L. Leibowitz
Global Asset Management and Performance Attribution

by Denis S. Karnosky and Brian D. Singer, CFA

Interest Rate and Currency Swaps: A Tutorial

by Keith C. Brown, CFA, and Donald J. Smith

Interest Rate Modeling and the Risk Premiums in Interest Rate Swaps

by Robert Brooks, CFA

The International Equity Commitment

by Stephen A. Gorman, CFA

Investment Styles, Market Anomalies, and Global Stock Selection

by Richard O. Michaud

Long-Range Forecasting

by William S. Gray, CFA

Managed Futures and Their Role in Investment Portfolios

by Don M. Chance, CFA

Options and Futures: A Tutorial

by Roger G. Clarke

Real Options and Investment Valuation

by Don M. Chance, CFA, and Pamela P. Peterson, CFA

Risk Management, Derivatives, and Financial Analysis under SFAS No. 133

by Gary L. Gastineau, Donald J. Smith, and Rebecca Todd, CFA

The Role of Monetary Policy in Investment Management

by Gerald R. Jensen, Robert R. Johnson, CFA, and Jeffrey M. Mercer

Sales-Driven Franchise Value

by Martin L. Leibowitz

Term-Structure Models Using Binomial Trees

by Gerald W. Buetow, Jr., CFA, and

James Sochacki

Time Diversification Revisited

by William Reichenstein, CFA, and Dovalee Dorsett

The Welfare Effects of Soft Dollar Brokerage:

Law and Ecomonics

by Stephen M. Horan, CFA, and

D. Bruce Johnsen 


\section{The Closed-End Fund Discount}


To obtain the AIMR Product Catalog, contact: AIMR, P.O. Box 3668, Charlottesville, Virginia 22903, U.S.A. Phone 434-951-5499; Fax 434-951-5262; E-mail info@aimr.org or

visit AIMR's World Wide Web site at www.aimr.org to view the AIMR publications list.

The Research Foundation of The Association for Investment Management and Research ${ }^{\mathrm{TM}}$, the Research Foundation of AIMR ${ }^{\mathrm{TM}}$, and the Research Foundation logo are trademarks owned by the Research Foundation of the Association for Investment Management and Research. CFA ${ }^{\circledR}$, Chartered Financial Analyst ${ }^{\mathrm{TM}}$, AIMR-PPS ${ }^{\circledR}$, and GIPS ${ }^{\circledR}$ are just a few of the trademarks owned by the Association for Investment Management and Research. To view a list of the Association for Investment Management and Research's trademarks and a Guide for the Use of AIMR's Marks, please visit our Web site at www.aimr.org.

(C) 2002 The Research Foundation of the Association for Investment Management and Research

All rights reserved. No part of this publication may be reproduced, stored in a retrieval system, or transmitted, in any form or by any means, electronic, mechanical, photocopying, recording, or otherwise, without the prior written permission of the copyright holder.

This publication is designed to provide accurate and authoritative information in regard to the subject matter covered. It is sold with the understanding that the publisher is not engaged in rendering legal, accounting, or other professional service. If legal advice or other expert assistance is required, the services of a competent professional should be sought.

ISBN 0-943205-61-1

Printed in the United States of America

December 13, 2002

\section{Editorial Staff}

Bette A. Collins/Christine E. Kemper

Book Editors

Kara E. Hite

Online Production
Jaynee M. Dudley

Production Manager

Kelly T. Bruton/Lois A. Carrier

Production and Composition 


\section{Mission}

The Research Foundation's mission is to encourage education for investment practitioners worldwide and to fund,

publish, and distribute relevant research. 


\section{Biographies}

Elroy Dimson is professor of finance and an elected governor of the London Business School, where he has served as chair of the Finance Area, chair of the Accounting Area, dean of M.B.A. Programs, and director of the Investment Management Program. Professor Dimson has held visiting positions at the Universities of Chicago and California, Berkeley, and at the Bank of England. He has been chair of a closed-end fund and an investment advisor and a director for several other funds. Professor Dimson is a former president of the European Finance Association and recently won the QGroup's Roger F. Murray Prize and the Most Innovative Paper Medal from Inquire. He has published articles in such journals as the Journal of Finance, Journal of Financial Economics, Journal of Business, Financial Analysts Journal, and Journal of Portfolio Management. His books include Stock Market Anomalies and Triumph of the Optimists: 101 Years of Global Investment Returns (with Paul Marsh and Mike Staunton). Professor Dimson holds degrees from the Universities of Newcastle, Birmingham, and London and was recently awarded an Honorary Fellowship of the Institute of Actuaries.

Carolina Minio-Paluello is executive director at Goldman Sachs Asset Management, London. As a product and portfolio manager, she is responsible for Goldman Sachs's quantitative and global balanced strategies in Europe and Asia ex-Japan. In previous positions with Goldman Sachs, she managed the global balanced product for the Global Fixed Income and Active Equity Teams and served in the Institutional Client Research and Strategy Group. Prior to joining Goldman Sachs, Ms. Minio-Paluello worked at J.P. Morgan Investments in the Strategic Investment Advisory Group. She is the recipient of the StyleAdvisor Prize for her research on returns-based style analysis, and she received the Edward Jones Scholarship Award at the London Business School for her research on closed-end funds. She has taught at the Universities of Geneva and London and has presented her research in a number of countries. Ms. Minio-Paluello was educated in Italy, Belgium, and the United Kingdom and holds a Ph.D. in finance from the London Business School. 


\section{Acknowledgements}

We are grateful for valuable suggestions from Gordon Gemmill, Don Keim, Julian Kozerski, Mark Kritzman, Stefan Nagel, Andrei Shleifer, Bill Ziemba, and colleagues at London Business School and Goldman Sachs. Financial support from the Research Foundation of AIMR is gratefully acknowledged. 


\section{Foreword}

The closed-end fund discount is one of the most persistent and troubling puzzles of financial economics and, as such, has generated an extensive literature of proposed resolutions. Elroy Dimson and Carolina Minio-Paluello offer a superbly organized and detailed review of the extant literature, including their own contributions.

They begin with a description of the closed-end fund industry, focusing on the variety of ways in which closed-end funds are structured and the regulatory environment in which they operate. They cover closed-end funds in both the United Kingdom and the United States, which allows them to evaluate certain hypotheses in light of the differences between these two markets.

Dimson and Minio-Paluello review the economic explanations of the discount within the context of the efficient market hypothesis. They address four types of explanations:

- The discount arises from biases in the funds' net asset values, such as tax liabilities and differences in liquidity.

- Agency costs account for the discounts. These costs include management fees, the expectation of poor performance, and the effect of ownership structure on the likelihood of opening the fund.

- The discount reflects the inability of investors to time gains and losses in order to reduce their tax liabilities.

- The discount is a result of market segmentation.

Dimson and Minio-Paluello scrutinize each of these explanations and find that, assuming markets are reasonably efficient, none of them individually accounts for all aspects of the closed-end fund discount.

The failure of economic hypotheses to explain the closed-end fund discount leads the authors to explore behavioral explanations. They consider whether investor sentiment might explain the discount. If investors have finite horizons, then the noise introduced by irrational investors who make systematic forecasting errors deters rational investors from engaging in the type of arbitrage that would eliminate the discount. Because rational investors are risk averse, they invest only in closed-end funds that sell at a discount as compensation for the incremental risk generated by the noise traders. Dimson and Minio-Paluello document evidence to support behavioral explanations of the puzzle, although they also find some contradictory evidence.

Finally, Dimson and Minio-Paluello examine ways to profit from the closed-end fund discount. Although they document evidence of apparent profitable opportunities, they acknowledge that implementation frictions may hinder the realization of these opportunities. 
This monograph presents a thorough review, including the authors' latest thinking, of one the greatest challenges to the efficient market hypothesis. The Research Foundation is pleased to present The Closed-End Fund Discount.

Mark Kritzman, CFA Research Director

The Research Foundation of the Association for Investment Management and Research 



\section{The Closed-End Fund Discount}

Closed-end funds are companies whose operations are similar to those of any business corporation. Closed-end funds differ only because their corporate business consists largely of investing funds in the securities of other corporations and managing these investment holdings for income and profit. An important characteristic that makes closed-end funds unique is that they provide contemporaneous and observable market-based rates of return for both stocks and underlying asset portfolios. Closed-end funds are so called because their capitalization is fixed, or "closed," which implies that the supply of closed-end fund shares is inelastic. Thus, the price is a function of the supply and demand for the shares trading on the market and has only an indirect link with the value of the assets corresponding to each share.

Closed-end funds are characterized by one of the most puzzling anomalies in finance-the closed-end fund discount. Shares in U.S. funds are issued at a premium to net asset value (NAV) of up to 10 percent; British funds are issued at a premium amounting to at least 5 percent. (This premium represents the underwriting fees and start-up costs associated with the flotation.) Subsequently, within a matter of months, the shares trade at a discount, which persists and fluctuates according to a mean-reverting pattern. On termination (liquidation or "open-ending"1) of the fund, share price rises and discounts disappear.

The flotation and subsequent behavior of closed-end fund shares, therefore, represent a challenge to the hypothesis that investors behave rationally and markets function efficiently. Closed-end funds provide apparent evidence of market inefficiency, violations of standard asset-pricing models, and exceptions to such fundamental principles of corporate finance as the law of the conservation of value and the Modigliani-Miller propositions. ${ }^{2}$ So, it is no surprise that closed-end funds have attracted the attention of leading scholars in finance.

\footnotetext{
1The term "open-ending" refers to a set of techniques that force a closed-end fund's share price to NAV. The methods include converting the fund to an open-ended structure, merging the fund with an open-ended fund, tender offers for the entire assets of the fund, and liquidating the fund's assets and distributing the proceeds to shareholders.

2See Dimson and Mussavian $(1998,1999)$ and Dimson and Talmor (2003) for reviews of these bodies of literature, and see Dimson (1988) and Keim and Ziemba (2000) for summaries of the literature on stock market anomalies as a whole.
} 
This monograph reviews the theories and evidence on the behavior of the discount on closed-end funds. ${ }^{3}$ We start by providing an overview of the closed-end fund industry. We then examine economic explanations for the discount, with particular attention to the managerial performance theory, and consider the behavioral explanations. Finally, we examine the opportunities for exploiting the discount.

\section{Closed-End Funds}

Since the launch in 1868 of the world's first closed-end fund, the Foreign and Colonial Government Trust (listed on the London Stock Exchange), the closed-end fund industry has grown considerably. 4 In the United States, the first closed-end fund, the New York Stock Trust, was offered to the public in 1889. Over the following century, the closed-end fund industry evolved to provide professionally managed portfolios aimed primarily at the individual investor. By the 1980s and 1990s, however, closed-end funds emphasized raising capital for investment in specialized areas or for special purposes, rather than for traditional, internationally diversified funds. In mid-2001, 470 funds were listed on the London Stock Exchange (LSE), with a total market capitalization of nearly $\$ 80$ billion (Dimson and Marsh 2001).5 The total market cap of U.K. open-end funds was then approximately $\$ 320$ billion (AUTIF 2001). British closed-end funds, therefore, have a market cap that is about one-quarter of the market cap of open-end funds. In the United Kingdom, closed-end funds and open-end funds are referred to, respectively, as investment trusts and unit trusts.

The assets of U.K. closed-end funds are invested almost exclusively in stocks. In contrast, the United States has two main types of closed-end fundsstock and bond. The Investment Company Institute (ICI 2002) reported that of $\$ 130$ billion invested in the closed-end fund industry in $2001, \$ 30$ billion was in equity funds; these equity funds had almost three-quarters of their assets invested in the United States. The aggregate market value of U.S. equity closed-end funds corresponds to less than 1 percent of the value of U.S. openend funds.

Table 1 provides an overview of the closed-end fund market, broken down into equity and bond funds and subdivided into domestic and foreign subgroups. Table 2 uses the sector classification prevalent in the United Kingdom to show a more detailed breakdown of British closed-end funds. These tables clearly demonstrate the wide variety of funds traded on the LSE.

3See Kraakman (1988) and Rozeff (1991) for earlier reviews of this literature.

4 Newlands (1997) recorded the history of the closed-end fund industry from its origins to the present day and provided references to other historical material.

5Values in sterling have been converted into U.S. dollars at an exchange rate of 1.42. 
Table 1. Overview of the Closed-End Fund Market, 2001

\begin{tabular}{|c|c|c|c|c|}
\hline \multirow[b]{2}{*}{ Fund Type/Category } & \multicolumn{2}{|c|}{ Number of Companies } & \multicolumn{2}{|c|}{ Sector Value (billions) } \\
\hline & United States & United Kingdom & United States & United Kingdom \\
\hline \multicolumn{5}{|l|}{ Equity funds } \\
\hline Domestic & 51 & 205 & $\$ 22$ & $\$ 30$ \\
\hline International and global & 59 & 149 & 8 & 50 \\
\hline All equity funds & 110 & 354 & $\$ 30$ & $\$ 80$ \\
\hline \multicolumn{5}{|l|}{ Bond funds } \\
\hline Domestic & 324 & 0 & $\$ 92$ & $\$ 0$ \\
\hline International and global & 24 & 0 & 8 & 0 \\
\hline All bond funds & 348 & 0 & $\$ 100$ & $\$ 0$ \\
\hline
\end{tabular}

Sources: ICI; Dimson and Marsh.

\section{Table 2. U.K. Closed-End Fund Categories}

\begin{tabular}{lcc}
\hline Category & Market Cap \\
(billions)
\end{tabular}

\section{A. Closed-end funds mid-1998}

1. International general

$<80 \%$ in any one geographical area ("area")

2. International capital growth $<80 \%$ in any one area; policy to stress capital growth

3. International income growth

4. U.K. general

5. U.K. capital growth

6. U.K. income growth

7. High income

8. Closed-end funds

9. Small companies

10. North America

11. Far East, excluding Japan

12. Far East, including Japan

13. Japan

14. Continental Europe

15. Pan Europe

16. Property

17. Commodity and energy

18. Emerging markets

19. Venture/development capital

20. Split-capital trusts

21. Venture capital trusts

Total

B. Closed-end funds mid-2001

1. Global growth

2. Global growth and income

3. Global small companies
$<80 \%$ in any one area; policy to stress income growth

$>80 \%$ in U.K.-registered ("U.K.") companies

$>80 \%$ in U.K. companies; policy to stress capital growth

$>80 \%$ in U.K. companies; policy to stress income growth

$>80 \%$ in equities/convertibles; yield $>25 \%$ above FTSE A.S.

$>80 \%$ in inv. trusts and other closed-end inv. companies

$>50 \%$ in the shares of small-/mid-cap companies

$>80 \%$ of assets in North America

$>80 \%$ of assets in Far East securities, ex Japan

$>80 \%$ in Far East securities; $<80 \%$ in Japan

$>80 \%$ of assets in Japan

$>80 \%$ of assets in continental Europe

$>80 \%$ in Europe (incl. U.K.); $>40 \%$ in continental Europe

$>80 \%$ of assets in listed property shares

$>80 \%$ of assets in listed commodity and energy shares

$>80 \%$ of assets in emerging markets

Significant portion in the securities of unquoted companies

Fixed open-ending date and $\geq 2$ classes of equity capital

Trusts, with a different tax status, invested in private equity

$<80 \%$ in any one area; $>20 \%$ in U.K.; stress on growth

$<80 \%$ in any one area; $>20 \%$ in U.K.; growth plus income

$<80 \%$ in any one area; $>20 \%$ in U.K.; $>80 \%$ small/mid-caps
$\$ 15$

7

2

4

2

\section{5}

11

1

6

2

4

3

2

3

2 


\section{Table 2. U.K. Closed-End Fund Categories (continued)}

\begin{tabular}{|c|c|c|c|}
\hline Category & Investment Policy & Number & $\begin{array}{c}\text { Market Cap } \\
\text { (billions) }\end{array}$ \\
\hline 4. Overseas growth & $<80 \%$ in any one geographical area; $<20 \%$ in U.K.; growth & 4 & 2 \\
\hline 5. U.K. growth & $>80 \%$ in U.K.-registered companies; growth stressed & 27 & 8 \\
\hline 6. U.K. growth and income & $>80 \%$ in U.K.-registered companies; growth plus income & 38 & 9 \\
\hline 7. U.K. small companies & $>80 \%$ in U.K.-registered companies; > 80\% small-/mid-caps & 36 & 5 \\
\hline 8. U.K. high income & $>80 \%$ in equities/convertibles; yield $>25 \%$ above FTSE A.S. & 36 & 4 \\
\hline 9. North America & $>80 \%$ of assets in North America & 7 & 2 \\
\hline 10. N. American small companies & $>80 \%$ of assets in North America; $>80 \%$ small-/mid-caps & 3 & $<1$ \\
\hline 11. Far East, including Japan & $>80 \%$ in Far East securities; $>20 \%$ in Japan & 3 & 1 \\
\hline 12. Far East, excluding Japan & $>80 \%$ in Far East securities; $<20 \%$ in Japan & 16 & 2 \\
\hline 13. Japan & $>80 \%$ of assets in Japan & 13 & 2 \\
\hline 14. Japanese small companies & $>80 \%$ of assets in Japan; $>80 \%$ small-/mid-caps & 5 & 1 \\
\hline 15. Europe & $>80 \%$ of assets in Europe & 17 & 5 \\
\hline 16. European small companies & $>80 \%$ of assets in Europe; $>80 \%$ small-/mid-caps & 5 & 2 \\
\hline 17. Global emerging markets & $>80 \%$ of assets in global emerging markets & 9 & 2 \\
\hline 18. European emerging markets & $>80 \%$ of assets in European emerging markets & 2 & $<1$ \\
\hline 19. Latin America & $>80 \%$ of assets in Latin America & 4 & $<1$ \\
\hline 20. Venture/development capital & Significant portion in the securities of unquoted companies & 22 & $<1$ \\
\hline 21. Country specialists & $>80 \%$ in 1 or 2 European/Far East/other countries & 14 & $<1$ \\
\hline 22. Sector specialists & Specialization in a particular sector & 46 & 4 \\
\hline 23. Split-capital trusts & Fixed open-ending date and $\geq 2$ classes of equity capital & na & na \\
\hline 24. Venture capital trusts & Trusts, with a different tax status, in private equity & na & na \\
\hline Total & & 354 & $\$ 80$ \\
\hline
\end{tabular}

na $=$ not available.

Notes: In Panel A, Sectors 1-15 were included in Dimson and Minio-Paluello (2002); Sectors 16-21 were omitted. In Panel $\mathrm{B}$, sectors were analyzed by CLL (2001). Split funds were allocated to sectors, and venture capital trusts omitted.

Sources: Association of Investment Trust Companies (sectors); Dimson and Minio-Paluello (2002); CLL.

The Discount. One important characteristic that sets closed-end funds apart from other collective investment schemes is the mismatch between the funds' share prices and the value of their underlying investments. The funds trade at a discount or premium to NAV. ${ }^{6}$ Investors, therefore, have two ways of making (or losing) money-from any rise or fall in the value of the underlying investments and from any narrowing or widening of the discount.

The history of the closed-end fund discount and premium mirrors the popularity of these funds. In the 1960s, the average discount fluctuated around 10 percent. However, by the middle of the 1970 s, private, as well as institutional, investors had lost interest in such funds and the average discount in the United Kingdom widened to nearly 50 percent. The bull market of the

${ }^{6} \mathrm{NAV}$ is defined as the market value of the securities held less the liabilities, all divided by the number of shares outstanding. 
1980s and the introduction of new investment objectives, capital structures, and tax-efficient wrappers renewed interest in closed-end funds. By the early 1990s, the average discount (expressed as the logarithm of the unweighted mean ratio of share price to NAV) had narrowed to around 5 percent, as Panel A of Figure 1 shows. During the 1990s, the trend seemed to reverse somewhat. By the beginning of 2001, however, the average discount of U.K. closedend funds was again below 10 percent.

\section{Figure 1. The Closed-End Fund Discount,}

\section{3-2001}

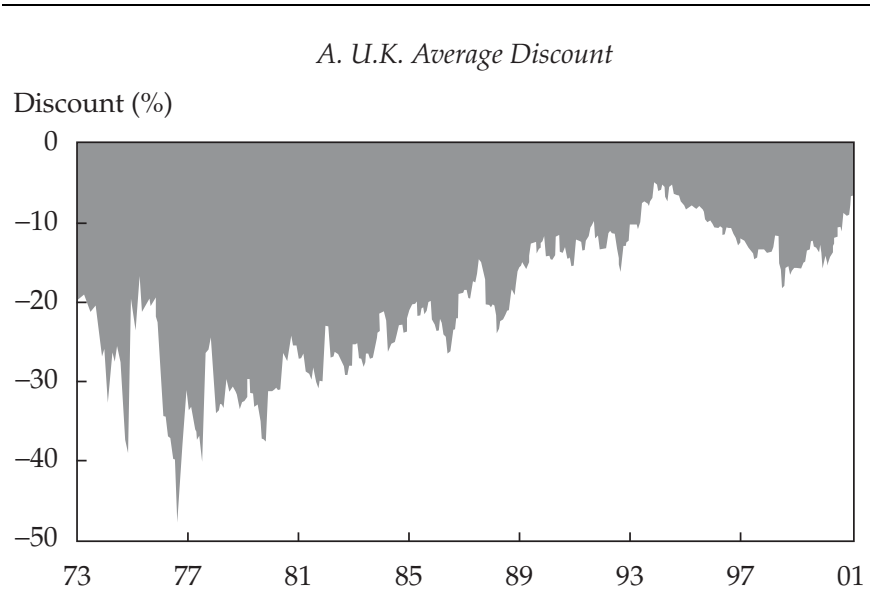

B. U.S. Average Discount

Discount $(\%)$

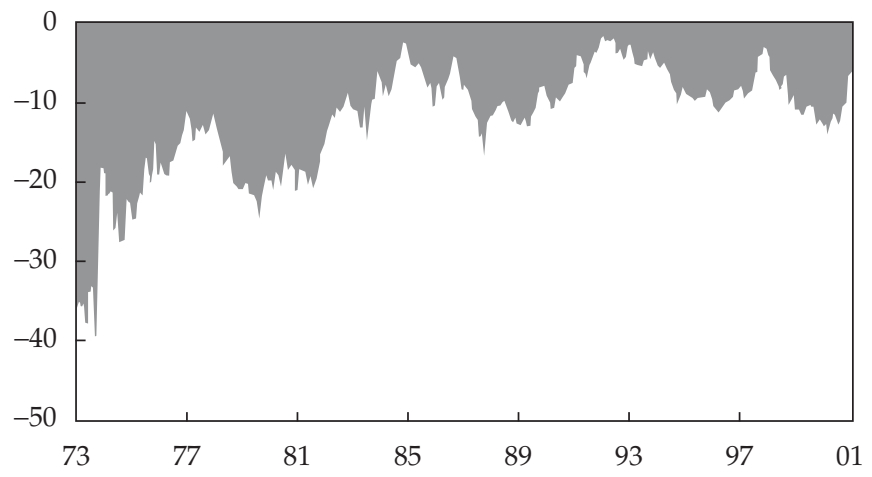

Note: U.K. data include almost the entire industry, with the exception of funds that invest in unquoted securities, specialist funds, and emerging market and split-capital funds.

Sources: Datastream (Panel A); CDA/Wiesenberger (Panel B). 
The behavior of U.S. equity domestic funds closely follows the pattern of the U.K. market. As Panel B of Figure 1 shows, during the 1970s, U.S. funds traded, on average, at a discount larger than 20 percent. Successively, the discount gradually narrowed until these funds traded at about a 5 percent average discount. Nevertheless, whereas U.S. closed-end funds are typically a retail product, a high level of institutional ownership exists in the United Kingdom. Two-thirds of the shares in U.K. closed-end funds, on average, are held by institutions, and for many funds, the institutional proportion is much higher than two-thirds (CLL 2001). Much of the academic research on closedend funds (reviewed in detail later) has focused on explaining the discount.

Regulations. In this section, we describe the structure and regulatory environment of the closed-end fund industry and draw a comparison between the United States and the United Kingdom. Some differences between closedend and open-end funds are also discussed.

- Capital structure. As discussed previously, closed-end funds are characterized by a fixed capitalization. This structure makes it easier for the investment manager to make long-term commitments. In contrast, open-end funds are characterized by the continual sale and redemption of their units at or near NAV, and this at the request of any unitholder. Therefore, open-end funds have a variable number of shares in issue.

Closed-end funds issue a wide variety of financial instruments, and their fund managers frequently devise new ways of providing investment exposure. Different classes of investment are now available. In the United Kingdom, they include ordinary shares, highly geared shares (common stock in a company with a windup date that is designed to give stockholders a highly leveraged return in terms of both capital and income), income shares (securities that are entitled to the surplus income after expenses and after the income requirement of any prior charge has been met), capital shares (securities that are entitled to the surplus assets on windup after repayment of other share classes), zerodividend preference shares (securities that have a predetermined rate of capital growth), stepped preference shares (securities with a predetermined growth in both income and capital), warrants, and convertibles.

Although only a few U.S. closed-end funds take on any leverage, 7 U.K. closed-end funds more frequently make use of leverage through their own capital structures. This use of leverage increases the underlying holdings of

7 Until 1988, no U.S. closed-end equity funds were leveraged. At the time we were researching this monograph, only 11 U.S. closed-end equity funds had any leverage and the aggregate debt ratio for this sector was less than 1 percent. The Investment Company Act of 1940 requires funded debt and preferred stock to be covered, respectively, at least three times and at least two times total assets (Anderson and Born 1992). 
a closed-end fund. The risk of highly leveraged shares is larger, however, because borrowing boosts NAVs in rising markets but depresses them when markets fall. To protect the interests of shareholders, there are restrictions on the amount of capital that a company may borrow, but the majority of funds operate with low levels of leverage, and prior to 2001, the limits in leverage had rarely been reached. ${ }^{8}$ In contrast, open-end funds are generally prohibited from borrowing money, which implies that unitholders' interests vary directly with the value of their proportionate part of the fund.

Split-capital funds are effectively a way of introducing an element of leverage without borrowing any money. In the United States, split-capital funds are referred to as dual-purpose funds. These funds are capitalized with two types of claim-preferred and capital shares-and have a fixed expiration date. Preferred shares receive all dividend and interest income as it accrues from the underlying portfolio of the fund and have a predetermined redemption price, when the fund terminates. Capital shares are entitled to the capital gains that the entire portfolio generates. ${ }^{9}$ Dual-purpose funds issue equal amounts of common and preferred shares. On termination, income shareholders receive the minimum of either their stated redemption price or the value of the remaining assets of the fund. Capital shareholders then have a residual claim on the terminal value of the fund's portfolio. At the windup date, one of two things usually happens-either the fund is liquidated and each shareholder receives his portion of the assets or, at the election of common shareholders, the fund can be converted into an open-end operation and continue as an investment company.

Warrants are long-term traded options that give the right to buy shares at some time in the future at a price fixed when the warrants are first issued. They are essentially call options. Warrants do not form part of the company's issued share capital, and they are usually not entitled to dividends until exercised (an exception to the rule is the "subscription share," which has all the features of a conventional warrant but also pays dividends). Well over 100

8As might be expected, during the 2000-2002 bear market, U.K. closed-end funds suffered serious declines, some breached covenants, and in certain cases, they were wound up. The declines were amplified in split-capital funds-not only through the leverage provided (e.g., by zero-dividend preference shares) but also through the additional leverage created in some funds by mutual cross-investment in other split-capital funds.

${ }^{9}$ The discount or premium on capital shares is computed by comparing the capital share price with the NAV. Most income shares have fixed redemption values over their lives; only a few have arrangements whereby they share in a portion of the capital growth over time. The net assets attributable to this class correspond to the estimated final redemption value. The overall split-capital fund discount is computed by summing the market capitalizations of all classes of shares and comparing the total with the sum of the net assets attributable to each class. 
closed-end fund warrants are traded in the London market. Most U.K. closedend funds include warrants with their share capital when they are first launched. Typically, an investor is offered one warrant for every five shares. Most warrants are "free" and are intended to compensate for any downward move in the share price from that price paid at launch. Investors can sell warrants once they are traded in their own right, separate from the shares. Warrants can easily be repurchased by the issuer.

Taxation. Under the U.S. tax system, closed-end funds are required to distribute to shareholders 90 percent of realized capital gains in a given year to qualify for exclusion from corporation tax. Closed-end funds make two types of distribution-the income dividend and the capital gains dividend. Shareholders are taxed according to the type of dividend received; the income dividend is taxed as ordinary income, and the capital gains dividend is taxed at the capital gains rate. Federal regulations require closed-end funds that elect to retain their beneficial tax status to return all dividend income to shareholders every year. Closed-end funds typically pay dividends quarterly or semiannually.

In contrast, U.K. closed-end funds are not allowed to distribute capital gains but must retain them for reinvestment. The capital gains tax on closedend funds was reduced to 10 percent in 1977 and removed completely in 1980. Therefore, closed-end fund managers can turn over their portfolios without incurring any capital gains tax liability. U.K. closed-end funds cannot retain more than 15 percent of dividends received. If the dividend they can distribute to their shareholders is lower than the desired level, they are prevented from selling part of their holdings to boost the dividend payout.

Charges. The costs associated with acquiring closed-end funds shares are typically lower than those for open-end funds. Open-end managers set an initial charge of about 5 percent when units are bought.10 The bid-offer spread, however, is often larger than the initial charge. In the United Kingdom, the calculation is strictly controlled by the Department of Trade and Industry and, in theory, can go as high as 12 percent. 11 In contrast, closed-end funds have no initial management charge when shares are bought, and the bid-offer

10The annual charge will be deducted before the investment income is distributed to unitholders, but the initial charge will normally be part of the buying price.

11The published spread is normally 5-7 percent, but managers are free to fix their prices anywhere within the permitted spread. On the one hand, an investor might have to buy the units when prices are being fixed in relation to the offer price and sell them when they are being fixed on the bid, so the spread can theoretically become as high as 12 percent. On the other hand, if the investor buys the units when prices are being fixed in relation to the bid price and sells them when they are being fixed at the offer, the spread can, in theory, disappear. 
spread is normally about 2 percent. The dealing costs involved in buying or selling through the investment trust management company can be as low as 0.2 percent, whereas a full-service stockbroker normally charges 1.65 percent. Considering the management charges and bid-offer spread as a whole, the cost associated with buying and selling closed-end fund shares can be markedly below 4 percent of the original investment and will never be above 8 percent. With open-end funds, the equivalent costs can be as high as 13 percent.

In the United States (and, to a lesser extent, the United Kingdom), some open-end companies, known as no-load funds, sell their shares directly to investors (see Morey, forthcoming 2003). Because no salesperson is involved, there is no sales commission (load) and the shares are sold at the net asset price. Others, known as load funds, offer shares through brokers or other selling organizations; these organizations add a percentage load charge to the NAV, and a portion of the investor's equity is removed as the "load" at the beginning of the contract. The load charge for a U.S. fund is generally about 8 percent of the sale price. It is possible but much less usual to buy units directly from existing unitholders. In the United States, the term "unit trust" is used in a more limited sense to refer to a fixed-unit trust-a company with a portfolio that is fixed for the life of the fund.

Closed-end fund managers take a fee for managing shareholders' assets, and out of this fee, they pay the costs of portfolio management. All cost savings that they achieve will increase their own profits. Conversely, it costs the shareholder no more if a trust is managed expensively. When a closed-end fund is able to reduce costs, doing so usually benefits the management company.

\section{Economic Explanations for the Discount}

Several standard theories about the pricing of closed-end funds attempt to explain the discount within the framework provided by the efficient market hypothesis. We discuss first the most obvious approach, which is to ask whether the discount is really there or whether the NAV is simply miscalculated; perhaps the market is efficient and the calculation of NAV contains biases. We turn in the following subsection to explanations based on agency costs. These explanations typically assert that the discount reflects the present value of management fees in excess of the value of services rendered, either before or after taking account of managerial performance. The tax-timing hypothesis we discuss next attempts to explain the existence of discounts based on the argument that by holding shares of a closed-end fund, investors lose valuable tax-trading opportunities associated with the idiosyncratic movements of the individual 
security prices in the portfolio. Finally, we present additional explanations for the discount that emphasize the impact of market segmentation.

As we move through these discussions, keep in mind that the explanations offered need to account for the premium as well as the discount

Biases in NAV. The dominant puzzle in the literature is the discount, so we first ask whether or not it is really there. Explanations of the discount that are consistent with a broad notion of market efficiency emphasize the possibility that NAVs may be overestimated. Possible causes of this miscalculation are tax liabilities relating to unrealized capital gains and illiquid assets. Another possibility is bias in the NAV arising from differences in liquidity between the underlying portfolio constituents and the shares of the fund.

Tax liabilities. As noted earlier, U.S. closed-end funds must distribute 90 percent of realized gains to qualify for exclusion from corporation tax. Thus, shareholders receive two streams of dividends - the income dividend and the capital gains dividend. An investor could buy fund shares worth $\$ 1,000$ and, with the fund then unwinding some profitable positions, take a $\$ 200$ capital gains distribution. Such an event would not only increase the effective cost of buying the shares, but tax would be due on a gain from before the investor owned the fund. If a closed-end fund is characterized by large unrealized capital gains, shareholders will be liable for capital gains taxes. Theoretically, this possibility might explain part (or all) of the discount on closed-end funds.

Malkiel (1977) found, however under fairly generous assumptions, that tax liabilities can account for a discount of no more than 6 percent, whereas the average discount of domestic equity funds in the United States has in recent years been almost 10 percent. Moreover, U.K. closed-end funds are not allowed to distribute any capital gains, and the shareholders are not liable for any capital gains tax unless they sell their holdings in the fund. Yet, U.K. funds behave remarkably like their U.S. counterparts (see Figure 1), which suggests that the discount cannot be explained by tax factors that are specific to a single country. Furthermore, the tax liabilities theory implies that on open-ending, the NAV should decrease. Lee, Shleifer, and Thaler (1990) showed the opposite: On liquidation, prices rise to the NAV.

Fredman and Scott (1991) argued that discounts may partially be caused by capital gains liabilities and suggested that if portfolio performance has been good and capital gains liabilities are large, discounts follow suit. Pontiff (1995) provided evidence, however, that past NAV returns, net of the market return, are more strongly related to current discounts than simple NAV returns, which is inconsistent with the capital gains arguments because capital gains are computed from unadjusted returns. 
The theory of capital gains tax liabilities predicts that when stocks do well, closed-end funds should accrue unrealized capital gains and, provided turnover rates on fund assets are constant, the discount should generally widen. However, Lee, Shleifer, and Thaler (1991-hereafter, LST) found that the correlation between returns on the market and changes in discounts is about zero.

Liquidity. Bookkeeping procedures could lead to a fund manager either under- or overestimating the fund's NAV. For example, reporting restricted shares at the same price as publicly traded common stocks can overstate the NAV.12 Malkiel found, for the 1969-74 period, a significant relationship between the discount and the variable measuring the proportion of the portfolio in restricted stock. Lee et al. (1990) showed that restricted holdings cannot explain much of the closed-end fund puzzle, however, because most funds are barely exposed to such illiquid securities but the funds still sell at a discount. More importantly, if restricted stocks were overvalued, the NAV should drop down on open-ending to the fund's price. Instead, the evidence shows that the share price, in fact, rises.

Liquidity-or, more precisely, lack of liquidity-is a possible explanation for the discount. On the one hand, Seltzer (1989) argued that discounts can be accounted for by the mispricing of illiquid securities in the portfolio. He suggested that these securities are likely to be overvalued because of the difficulty of determining their fair market value. In this connection, Datar, Naik, and Radcliffe (1998) demonstrated the importance of liquidity in terms of explaining stock returns. On the other hand, investors might be willing to pay higher management fees for holding the liquid shares of closed-end funds that invest in less liquid securities, such as small-cap stocks. Therefore, the importance of illiquid assets is difficult to measure.

Datar and Dubofsky (1999) also showed that closed-end funds react no differently from other firms to stock distribution announcements. Trading volume and turnover remain unchanged after closed-end funds' ex-stockdistribution days, although for other firms that distribute shares, liquidity declines.

Closed-end funds hold diversified portfolios of stocks and report the market values of their underlying assets weekly. Consequently, the little uncertainty about their current liquidation values should not generate an adverse selection component in fund bid-ask spreads. Neal and Wheatley (1998a) found, however, that estimates of the adverse selection component of

12 Restricted or "letter" stocks are like common stocks except that they must be held for investment and cannot be sold for a prespecified period of time. These stocks are unregistered and highly illiquid, which implies that the market price of these stocks is not a fair indication of their liquidation value. 
a firm's bid-ask spread are large and significant for both closed-end funds and a matched sample of common stocks. Their evidence suggests that either adverse selection arises primarily from factors other than current liquidation values or the empirical models are misspecified. Note, however, that in contrast to Neal and Wheatley's findings, Clarke and Shastri (forthcoming 2003) have found that the adverse selection component of closed-end fund spreads is lower than it is for control firms.

$\mathrm{Wu}$ and Xia (2001a, 2001b) took a different perspective on liquidity. Focusing on country funds, they perceived discount changes to be instruments for expected future economic conditions, so the discount proxies for the expectation of future liquidity risk.

Finally, Deli and Varma (2002) investigated whether the choice of fund organization plays a role in the discount. They found that funds that hold the less liquid assets, because of the less transparent pricing of those securities, are more likely to be closed-end funds. The relationship is economically meaningful as well as statistically significant.

In summary, most researchers conclude that the discount cannot be explained away by biases in the calculation of fund NAVs. This series of explanations is consistent with neither the existence of premiums to NAV nor with the empirical regularity of price rises at open-ending.

Agency Costs. Agency costs are a possible explanation of the closed-end fund discount if fees and expenses are considered too high or if future portfolio management is expected to be below par. From this point of view, the discount reflects excessive management fees and/or inadequate management performance. This approach has several problems. Positive agency costs imply that funds should never be issued at a premium as long as equivalent no-load openend funds charging comparable fees exist. Furthermore, agency costs account neither for the wide cross-sectional and periodic fluctuations in the discounts nor for why some closed-end funds trade at a premium. An additional drawback of this hypothesis is that it cannot explain why rational investors buy into closed-end funds that are issued at a premium; rational investors would be aware of the likelihood of the fund subsequently trading at a discount.

Management fees. The simplest interpretation of the agency approach predates Jensen and Meckling's seminal 1976 paper on agency theory. It focuses on management fees and other expenditures as a deadweight cost imposed on shareholders of a closed-end fund. As Baur, Coelho, and Santoni (1996) explained, because of this cost, the discount on closed-end funds is a consequence of investors anticipating possible managerial dissipation and capitalizing future management fees. Malkiel found no correlation, however, between U.S. discounts and management expenses as a proportion of NAV (see also Boudreaux 1973). 
Turnover has also been suggested as a possible explanation for the discount, because some closed-end fund managers execute a large volume of discretionary transactions. Yet, Malkiel found no correlation between discounts and turnover. Furthermore, agency theory predicts that when long-term interest rates fall, the present value of future management fees should rise and discounts increase. LST showed, however, that changes in discounts are not correlated with unanticipated shifts in the term structure of interest rates.

Ammer (1990) showed that with both a simplified static version and a dynamic version of an arbitrage-based framework, expenses and yields account for a level of the discount that is typical of U.K. closed-end funds. Ross (2002) supported the view that discounts can be explained as the present value of managerial fees. However, this framework fails to explain most of the time series, cross-sectional, and international variations in discount. Kumar and Noronha (1992) reexamined the role of expenses by developing a present value model that emphasizes expenses relative to dividend income. Using a larger sample than Ammer used and their alternative specification of the expense variable, Kumar and Noronha found that discounts are related to expenses.

Gemmill and Thomas (2002) addressed the existence of a long-run equilibrium discount on closed-end funds and the reason the discount fluctuates over time. They argued that discounts exist in the long term because of management expenses and the asymmetry of arbitrages and that discounts fluctuate in the short term because of changes in investor sentiment.

Managerial performance. Many funds, both closed-end and open-end funds, experience costs that are larger than the value of the investment manager's expertise. Therefore, as Ferguson and Leistikow (2001) suggested, the economic value of a portfolio can differ from its NAV. The shares of closed-end funds would generally sell at a discount or earn an abnormally low return on investment. We call this idea the "performance theory" of closedend fund discounts.

Thompson (1978) did not support this hypothesis. He observed that over long time periods, many funds sell at a discount but simultaneously earn, on a before-tax basis, greater rates of return than can be justified by the twoparameter capital asset pricing model. Similarly, Malkiel found no significant relationship between future fund performance and discount levels. Roenfeldt and Tuttle's (1973) marginal support for a contemporaneous relationship is anomalous, but it relates to a very small sample.

Assuming rational expectations, the performance theory predicts that large discounts reflect poor future NAV performance. Lee et al. (1990) did not support this hypothesis. They found that assets of funds trading at large discounts tend to outperform those with smaller discounts. Furthermore, Pontiff (1995) showed that the ability to predict future discounts based on 
current discounts is almost entirely attributable to the ability to forecast stock returns (as opposed to NAV returns).

Gruber (1996) and Elton, Gruber, and Blake (1996) showed that investors can, and do, identify superior managers and direct incremental money to the open-end funds that are better managed. Zheng (1999), examining the statistical and economic significance of Gruber's "smart money" effect, confirmed the existence of fund selection ability. Chen, Jegadeesh, and Wermers (2000) presented findings for growth-oriented mutual funds that are consistent with the existence of fund selection ability. Bal and Leger (1996) and Leger (1997) reported weak performance persistence among British closed-end funds, and comparable results for the United States were presented by Bers and Madura (2000). In a very different environment, Chen, Rui, and Xu (2002) and Cao and Esman (2002) found evidence of superior and persistent managerial performance among Chinese closed-end fund managers.

On the one hand, if the superior funds are drawn from the universe of closed-end funds, discounts should reflect investor expectations of future managerial performance, and Gruber suggested that funds might trade at a smaller discount (or even at a premium) if the market were anticipating good managerial performance. Chay (1992) and Chay and Trzcinka (1999), calculating managerial performance net of expenses charged by managers, showed that funds selling at a discount do underperform funds selling at a premium. These findings tend to support the hypothesis that discounts reflect market expectations of fund managers' future performance. Bodurtha, Kim, and Lee (1995) concluded that at a monthly horizon, discounts are not mean reverting, yet they predict future price returns, and $\mathrm{Wu}$ and Xia (2001a) found that discounts predict future NAV returns. These findings, therefore, tell a story similar to Chay and Trzcinka's findings.

On the other hand, despite the belief that discounts should reflect the quality of management of closed-end funds, the existing evidence presents something of a puzzle, in that discounts appear to be negatively related to subsequent measures of performance. In Dimson and Minio-Paluello (2001), we found that larger discounts (a low ratio of price to NAV) tend to be associated with high share price and NAV returns, although this relationship is mostly not statistically significant. Consistent with Malkiel and with Pontiff (1995), the results demonstrated that smaller discounts (a high ratio of share price to NAV) are not associated with the expectation of higher NAV returns. The difficulty of identifying a link between closed-end fund discounts and managerial performance helps explain why so few studies have looked at managerial performance. Either the expected link between the discount and subsequent performance does not exist, or investigators need a more sophisticated test procedure. 
For this reason, Dimson and Minio-Paluello (2001) revisited the managerial performance theory predicting that if a fund pays more than the "fair" value for managerial expertise, its shares should sell at a discount, and vice versa. In that paper, instead of defining managerial performance as the fund's NAV return (as previous research had done), we introduced a measure of managerial performance that adjusts for the fund's effective asset exposure. This definition of performance can capture the manager's ability to select the "right" stocks. The idea is that if a fund is simply exposed to an asset class that is doing well, the manager is not necessarily good. The manager outperforms only if he or she does better than a passive strategy with the same asset mix.

We used multi-index models to adjust for the fund's effective asset exposure to obtain a refined measure of managerial performance. NAV returns, rather than share price returns, were used to judge managerial performance because they are not affected by fluctuations in the discount. Our analysis of the relationship between discounts and managerial performance suggests that price weakly reflects past performance but incorporates no expectations of future performance. Bleaney (2002), again using U.K. data, confirmed this finding.

Finally, Deaves and Krinsky (1994) suggested a possible reconciliation of the conflicting findings on the role of managerial performance in closed-end fund discounts. They investigated the puzzling evidence that managerial contribution (the difference between managerial performance and managerial fees) and discounts are not negatively related. They showed that some of the findings can be explained without abandoning market efficiency. Their model has its foundations in the principle of investor rationality and shows that the relationship between managerial contribution and discounts is not necessarily monotone. Specifically, they argued that investors may attach an increased probability to open-ending, which by definition moves the price toward the NAV, in which case, as managerial contribution declines, the discount narrows.

Agency problems. Agency problems have the potential to provide an explanation for the existence of the discount. Agency theory focuses on the relationship between the principal (the shareholder of the fund) and the agent (the manager). Agency problems emerge when conflicts of interests between agents and principals affect the operations of the company or fund.

Draper (1989) investigated the U.K. fund management market and observed that U.K. closed-end funds are rarely managed in-house but, rather, contract out their management to groups of specialists. These potentially lucrative contracts act as an incentive to managers to impede shareholder asset realization as a result of open-ending. Consequently, shareholders may be forced to bear substantial costs because of the difficulty of displacing 
management and liquidating their holdings. To some extent, U.S. evidence supports this hypothesis (Thompson; Brauer 1984; Barclay, Holderness, and Pontiff 1993). The very low levels of liquidation and open-ending costs revealed over the period spanned by Draper's study suggest that far more British funds could profitably have been liquidated with beneficial effects for the shareholders of the fund. Intriguingly, he also showed, however, that closed-end fund managers receive considerably higher fees on open-ending; consequently, open-ending could be in their interest.

Additional evidence supporting agency problems is suggested by Barclay, Holderness, and Pontiff (1995). They found a stable and significant crosssectional relationship between discounts and the concentration of ownership. The greater the managerial stock ownership in the closed-end fund, the larger the discounts to NAV. The average discount for funds with blockholders was 14 percent, whereas the average discount for funds without blockholders was only 4 percent. The idea is that blockholders receive private benefits that do not accrue to other shareholders and, therefore, tend to preserve those benefits by vetoing open-ending proposals. Consistent with Barclay et al.'s story, Clarke and Shastri found a positive relationship between blockholdings and the adverse selection component of the bid-ask spread.

The literature advances two competing hypotheses about how the relationship between managerial stock ownership and firm value could generate agency problems. One is the convergence-of-interest theory, and the other is the entrenchment hypothesis. The results for closed-end fund companies are consistent with the entrenchment hypothesis. That is, when managers have effective voting control of the corporation, they are able to consume private benefits with little fear of a hostile control contest. The prediction is that as management holding increases, firm value will decrease. In contrast, the convergence-of-interest theory predicts that as management holdings increase, managers bear a larger fraction of the costs associated with nonvalue-maximizing behavior and thus are less likely to engage in such behavior. Consequently, firm value will increase. Empirical studies attempting to distinguish between these two competing hypotheses have produced mixed results; see, for example, Morck, Shleifer, and Vishny (1988) and McConnell and Servaes (1990).

Coles, Suay, and Woodbury (2000) examined the relationship between the premium on closed-end funds and organizational features of the funds, including the compensation scheme of the investment advisor. They found that the fund premium is larger when the advisor's compensation is more sensitive to fund performance and the assets managed by the advisor are concentrated in the fund in question. The evidence also suggests that evaluating advisor 
performance relative to a benchmark is associated with a substantially larger premium.

Dann, Del Guercio, and Partch (forthcoming 2003) investigated the monitoring role of closed-end fund directors and argued that fund expense ratios are the most visible manifestation of the board's effectiveness in executing its charge. They analyzed board composition, board size, director compensation, capital structure, ownership structure, and governance-related charter provisions in 476 closed-end funds. They found that boards with a greater degree of effective independence are associated with lower expense ratios.

To sum up, agency problems can account for part of the level of the closedend fund discount. Nevertheless, the theories cannot explain the large fluctuations in discounts.

Tax Timing. A number of authors have attempted to justify the discount of closed-end funds by the effect of the tax liabilities associated with unrealized capital gains. Taxes may have an opposite effect, however, because closed-end funds provide investors the opportunity to control their tax exposure through careful timing of stock exchange transactions.

Constantinides' $(1983,1984)$ investigations of the influence of taxes on security returns are relevant to a study of the closed-end fund discount. Constantinides posited that the ownership of individual common stocks confers on the investor a timing option because taxes on capital gains and losses are levied based on realization, not accrual. He argued that the optimal taxtiming strategy is to realize capital losses immediately and defer capital gains until a forced liquidation. Constantinides also showed that, compared with a suboptimal policy of never voluntarily realizing capital losses, the optimal taxtrading strategy would generate a tax-timing option value that constitutes 3-19 percent of the value of the position in the stock.

The relevancy of Constantinides' results to the discount anomaly is tied to Merton's (1973) option-pricing theorem, which states that for all options, including tax-timing options, a portfolio of options is more valuable than an option on the corresponding portfolio. Managed funds deny taxable investors the tax-timing option available through holding the underlying securities that constitute their portfolios. Therefore, when the fund is structured to be a closed-end fund and the marginal investors are in a tax-paying position, the fund should sell for less than its NAV.

Cuny (1997) examined the tax effects associated with investing in openend mutual funds relative to direct investment in the underlying portfolios of securities. Because mutual fund distributions treat all shares identically, regardless of when the shares were purchased, new investments in mutual funds may face a tax "overhang" (that is, a potential tax-timing liability 
associated with unrealized capital gains). Mutual funds are tax disadvantageous (relative to direct security investment) for short-term investors. But because later-arriving investors generally share the tax burden, mutual funds can be tax advantageous for long-term investors.

Models. Brickley, Manaster, and Schallheim (1991) and Kim (1994) developed models to find an explanation of the closed-end fund discount based on research into taxes and the discount. Both research teams found evidence consistent with the hypothesis that the closed-end fund discount is partly driven by the fact that as a result of holding shares in a closed-end fund, investors lose valuable tax-trading opportunities associated with the idiosyncratic movements of the individual portfolio constituents. Brickley et al. showed that, crosssectionally, discounts are positively correlated with the average variance of the constituent assets in the fund and that in time series, the value of the discounts varies counter-cyclically. 13

Kim used the state-preference framework to develop a one-period-horizon model for discounts on closed-end funds. The model predicts that high correlations among assets will result in low discounts (or even no discounts) 14 and that funds with more volatile securities will show greater discounts than funds with less volatile securities in their portfolios. 15 Kim's evidence is broadly supportive of his model.

The strategy of deferring taxable capital gains provides the highest aftertax returns for both closed-end and open-end funds in the United States, because the tax laws affect each identically. Yet, open-end funds regularly distribute a large fraction of their total returns to investors as taxable capital gains. Barclay, Pearson, and Weisbach (1998) developed a model that explains this result. Unrealized capital gains in the fund's portfolio increase expected future taxable distributions and thus increase new investors' tax liabilities. So, even though existing shareholders would prefer capital gains to be deferred as much as possible, mutual fund managers have an incentive to reduce the overhang of unrealized gains to attract new investors. Kraft and Weiss (2001)

13Discounts appear to increase during stock market declines and decrease during stock market increases. These findings are consistent with Schwert's (1989) results showing that stock return variances tend to increase during business downturns.

14In the extreme case, in which all assets are perfectly correlated, there are no discounts because the value of a portfolio of options on underlying securities is equal to the value of an option on the portfolio composed of the same underlying securities. For example, bond funds should have lower discounts than diversified funds because changes in the general level of interest rates affect the prices of various bonds in a similar way. For 1979-1988, the average discount on diversified funds and on bond funds was, respectively, 6.9 percent and 4.9 percent. 15Brickley et al. found a similar result, but they did not consider correlations between assets. 
showed that because closed-end funds do not have to worry about potential new investors, the funds tend to shift capital gains realizations from periods of high capital gains tax rates to periods of lower rates.

Empirical evidence. Evidence from the U.S. closed-end fund market tends to support the tax-timing option argument. Prior to 1986, investors in common stocks could follow a "restart strategy." Taxable investors who followed this strategy realized long-term gains on those stocks that had performed well in order to realize short-term losses in underperforming securities. This strategy was beneficial because long-term gains were taxed at a lower rate than short-term gains. 16 The 1986 Tax Reform Act eliminated the favorable tax treatment of capital gains by making capital gains income taxable as ordinary income and made the long- and short-term capital gains tax rates equal. The end of the restart option effectively made the tax law less disadvantageous to closed-end funds. Consequently, the number of closedend funds increased dramatically after 1986.17

Unfortunately for this argument, the discount on U.S. closed-end funds progressively widened between 1985 and 1990, as De Long and Shleifer (1992) showed. Moreover, the U.K. closed-end fund market does not provide much evidence in support of the tax-timing argument. The restart option was effectively eliminated in the United Kingdom in 1985,18 and the average discount progressively narrowed from 20 percent in 1985 to 5 percent in 1990, but the lack of statistical tests and a dramatic increase of the discount thereafter suggest that the tax-timing argument cannot alone explain the closedend fund anomaly.

Seyhun and Skinner (1994) showed the relevance of the tax-timing option in terms of the extent to which investors' transactions are motivated by tax code incentives. The results tend to indicate that investors' trades are consistent with simple tax-reduction strategies, such as realizing losses short term and deferring gains, but are not consistent with the restart option suggested by Constantinides. Seyhun and Skinner estimated that in a given year, only a small fraction (5-7 percent) of investors trade to reduce their tax payments; the large majority (90 percent) buy and hold stocks. Overall, their results show

16Constantinides (1984) provides further analysis of the restart option.

17In March 1983, 45 closed-end funds operated in the United States, with total assets of $\$ 7$ billion. By 1991, the number had jumped to 270, with total assets (including bond as well as equity funds) of $\$ 60$ billion. Kim documented the average number of closed-end funds before and after 1986; the respective means he found, 55 and 153, are significantly different.

18In the United Kingdom, the differential taxation between long-term and short-term capital gains was addressed in two stages. In 1982, the tax rates were made equal, but it was not until 1985 that indexation of short-term capital gains was introduced. 
that taxes are important to investors but not to the extent that investors continually adjust their portfolios to minimize the present value of their net tax payments. These results also cast doubt on the potential importance of tax timing as an explanation of the discount.

The tax-timing hypothesis as formulated in the published literature cannot account for funds selling at a premium. But the introduction of morecomplicated capital structures potentially allows the tax-timing argument to be consistent with premiums as well as discounts to NAV. Examples of such structures are (1) zero-dividend securities, popular in the late 1990s in the United Kingdom, which can generate a tax-free capital gain, and (2) incomeproducing securities, which can be held by U.K. investors free of income tax within a tax-efficient wrapper. 19 These tax-driven capital structures provide investors with potential tax efficiency that is not available from holding the underlying constituents of a fund (Gemmill 2001). 20

Finally, note that tax-timing explanations of the discount are not mutually exclusive with other explanations, and multiple factors may contribute to the discount. The evidence indicates that only a small proportion of investors trade to reduce their tax payments and that the majority buy and hold stocks for the long term.

Market Segmentation. Another group of explanations for the closedend fund discount focuses on various forms of market segmentation. By providing a means of overcoming home-country bias, closed-end funds may provide domestic investors with exposure to nondomestic markets, or may expose one type of investor to markets whose returns are determined by a different group of domestic investors. Moreover, funds may be priced at a level that reflects private investors' responses to a fund manager's sales effort or the difference in valuations between institutions and individuals. In this section, we document the extent to which both international and local market segmentation provide interesting implications for the closed-end fund discount puzzle.

19Many countries have mechanisms for "wrapping" a holding of securities within a tax-efficient structure. In some countries, these wrappers are limited to IRAs; wrapping these accounts can present problems if the investor wishes to access funds prior to retirement. In the United Kingdom, however, tax-efficient wrappers include Personal Equity Plans and Individual Savings Accounts, which allow an investor to make stock market investments that are tax exempt yet accessible if the investor wishes to sell some or all of the portfolio.

20 Note, however, the dangers of creating tax advantages through leverage. In the United Kingdom, zero-dividend securities were sold to some investors as low-risk securities, even though their value was, in fact, highly sensitive to adverse market movements. The market declines of the early 2000s revealed the high credit risk of many zeros issued by closed-end funds. 
International market segmentation. One form of segmentation arises internationally. The evidence from Cooper and Kaplanis (1994) and Dimson, Marsh, and Staunton (2002) on the home bias in investors' portfolios indicates that domestic investors incur costs when they diversify into foreign markets. These costs are likely to be particularly high when investors diversify out of a developed domestic market, such as the United States, into underresearched, less well-regulated, and inaccessible foreign markets. The growth of emerging market funds suggests segmentation between the United States and emerging markets that has not been eliminated. Holdings of foreign stocks may, therefore, help explain the existence of premiums and discounts.

Some closed-end funds, referred to as country funds, invest exclusively in foreign securities. The existence of restrictions on direct foreign investment is a possible explanation for their trading at certain times at a premium. Bonser-Neal, Brauer, Neal, and Wheatley (1990) tested whether a relationship exists between announcements of changes in investment restrictions and changes in the ratio of price to NAV. Using weekly data from 1981 to 1989 , they found that four out of five country funds experience a significant decrease in their price-to-NAV ratios following the announcement of a liberalization of investment restrictions. German and Spanish funds, however, which invest in completely open markets, sold at large premiums in the $1980 \mathrm{~s}$, sometimes at prices above 200 percent of NAV (see Hardouvelis, La Porta, and Wizman 1994). Furthermore, Malkiel found no significant relationship between discounts and holdings of foreign stocks.

A second factor that might explain premiums and discounts on country funds is the extent of "integration" between country funds and the markets in which they are traded. Investigating the potential for closed-end country funds to provide international diversification, Chang, Eun, and Kolodny (1995) showed that funds exhibit significant exposure to the U.S. market and behave more like U.S. securities than do their underlying assets. This evidence supports Bailey and Lim's (1992) finding that country funds are poor substitutes for direct holdings of foreign securities. Bodurtha et al. also showed that returns on country funds are more correlated with U.S. market returns than the underlying indexes. Chang et al. argued, however, that closed-end country funds provide U.S. investors with substantial diversification benefits. In particular, emerging market country funds (such as Brazil, Mexico, and Taiwan funds) are shown to play a unique role in expanding the investment opportunity set.

Bekaert and Urias (1996) used an extensive dataset on U.S.- and U.K.traded closed-end funds to examine the diversification benefits of the emerging equity markets. They found significant diversification benefits for the U.K. country funds but not for the U.S. funds, which appears to result from 
differences in portfolio holdings rather than from differences in the behavior of U.S. premiums versus U.K. premiums (see also Choi and Lee 1996).

Errunza, Senbet, and Hogan (1998) provided a theoretical and empirical analysis of country funds that focused on emerging economies whose capital markets are not readily accessible to outside investors. They showed that country funds traded in the developed capital markets can be beneficial in promoting the efficiency of pricing in the emerging capital markets.

Klibanoff, Lamont, and Wizman (1998) investigated the hypothesis that the relative salience of news plays a role in the magnitude of investor reaction to changes in economic fundamentals. They used a panel of cross-sectional and time-series data on prices and NAVs to test whether dramatic countryspecific news affects the response of closed-end country fund prices to asset values. The results are consistent with the hypothesis that news events lead some investors to react more quickly and lends support to the notion that discounts can fluctuate in accordance with releases of relevant news.

Levy-Yeyati and Ubide (2000) included evidence from the Mexican and East Asian crises in their analysis of the behavior of closed-end country-fund discounts. They found that the ratio of fund price to fundamental value increases dramatically during a crisis-an anomaly that they referred to as the "closed-end country fund puzzle." Their results show that the puzzle relates directly to the fact that international investors are less sensitive to changes in local market conditions than domestic investors and more sensitive to changes in global market conditions than domestic investors. This asymmetry implies that foreign participants in local markets can help dampen a crisis in the originating country and amplify the contagion to noncrisis countries. Kramer and Smith (1998) also investigated the behavior of countryfund discounts at the time of the Mexican peso crisis. The events of December 1994 in Mexico and subsequent effects on some funds' prices gave rise to a new puzzle-extreme premiums on closed-end funds that invested in Mexican stocks. As a possible explanation for the phenomenon, Kramer and Smith hypothesized that individual investors are averse to taking large losses on their investments.

Nishiotis (1999) investigated the effect of direct and indirect investment barriers on the premium of closed-end country funds. Using a simple model to show the links among investment barriers, equity flows, and closed-end country-fund premiums, he found that developed countries do not exhibit evidence of market segmentation and their fund premiums are strongly associated with the premium on U.S. domestic closed-end funds. In contrast, most emerging markets exhibit strong evidence of market segmentation. The measure of market segmentation for all segmented markets except Chile, however, showed a trend toward integration. 
Bailey, Chan, and Chung (2000) studied the intraday impact of exchangerate news on emerging market American Depositary Receipts (ADRs) and closed-end country funds during the 1994 Mexican crisis. They concluded that peso information has a significant impact on the pricing and trading volume of emerging market ADRs and closed-end country funds. In particular, some evidence suggested that the closed-end fund market (dominated by small investors) is more sensitive to Mexican news than the ADR market (dominated by institutional investors). They found no evidence that peso depreciation at the time triggered significant sell-off of non-Mexican securities.

Finally, Patro (2001) examined the performance of 45 U.S. closed-end international mutual funds between January 1991 and August 1997 and found no evidence that the risk-adjusted performance of the sample of international closed-end funds outperformed the world market index. The underperformance was small, however, and not statistically different from zero. If the expenses of the funds had been lower, they would have outperformed the world market index. Patro also showed that domestic mutual funds in the United States underperformed the market index, which suggests that closedend international funds may provide superior performance compared with pure domestic funds.

Local market segmentation. As Huberman (2001) demonstrated, markets may also be segmented domestically. Several articles have drawn a distinction between different investor groups, usually institutions and private individuals, in a domestic market. The time-series behavior of the discount, then, could reflect the responsiveness of different group to such factors as the sales effort by initial public offering (IPO) promoters or the relative market power of institutional investors.

Pratt (1966) and Malkiel and Firstenberg (1978) suggested that U.S. closed-end investment companies sell at a discount to open-end funds primarily because of a lack of sales effort for and public understanding of closedend funds. Anderson (1984) and Malkiel supported this hypothesis and argued that brokers prefer to sell securities other than closed-end fund shares because of lower commissions on closed-end funds. 21 Furthermore, Anderson showed that after the reduction of commission levels in 1975, which in all probability reduced sales efforts, U.S. discounts increased.

A related explanation is the oversupply argument posed by Arnaud (1983). He, together with a variety of subsequent writers, argued that the U.K. closedend fund market is segmented and dominated by institutions that distort the

21 Malkiel argued that investors usually do not "buy" investment funds; rather, the public is sold funds by brokers or sales staff. 
prices. ${ }^{22}$ The idea is that, consistent with the empirical evidence of the steady stream of sales by individual investors (in particular, in the 1965-85 period), institutions are prepared to buy shares of closed-end funds. But they can, to a large extent, influence the price in terms of the discount at which they are willing to buy. The discount is a reflection, therefore, of the oversupply of prepackaged portfolios of securities.

Conclusions on Economic Explanations. This extensive review has addressed possible economic explanations for the closed-end fund discount. We examined approaches to the discount puzzle that draw solely on the paradigms of market efficiency and standard financial economics, and we showed that these approaches are unable to provide a full resolution of the puzzle.

The first justification for the existence of the discount is that it might reflect overestimated NAV (i.e., tax liabilities related to unrealized capital gains or differences in liquidity). The literature tends to suggest that part of the level of the discount could be accounted for by biases in the NAV. Nevertheless, the series of explanations is consistent with neither the existence of premiums to NAV nor the empirical regularity of prices rising at open-ending.

Agency costs might explain the existence of the discount on closed-end funds if management fees were excessive or if management were expected to underperform. Agency problems relating to the ownership structure might also explain part of the level of the discount. Nevertheless, agency theories cannot account for closed-end funds trading or being issued at premiums or for the large fluctuations in the discount.

The tax-timing hypothesis attempts to explain the closed-end fund discount in terms of the loss of valuable tax-trading opportunities associated with the idiosyncratic movements of individual shares, but this theory is inconsistent with evidence that investors' trades are barely motivated by tax considerations.

Finally, a group of explanations focuses on various forms of market segmentation, but these approaches are unable to account for all the anomalies related to the pricing of closed-end funds.

In short, although several economic explanations have been put forward, none can resolve all parts of the closed-end fund puzzle. This failure to explain the discount within a rational framework has directed the literature toward behavioral hypotheses.

22The ownership structure of U.K. funds has changed considerably over the years. In 1964, individuals held almost 60 percent of U.K. closed-end funds, but their stake had fallen by 1984 to below 25 percent. The increase in the proportion of institutional shareholders to some 75 percent by 1990 has, however, begun to reverse. 


\section{Behavioral Explanations of the Discount}

The failure of standard economic theories to explain the anomalous behavior of the discount on closed-end funds casts doubt on the rationality of the market. Furthermore, premiums seem to occur at times of great investor enthusiasm about stocks in general (such as the late 1920s or mid-1980s) or times of investor enthusiasm about particular securities (such as stocks exposed to certain countries).

Some closed-end country funds have experienced, in addition to high volatility in the value of the underlying assets, violent stock-price fluctuations that cannot be related to the state of the foreign market. An anecdotal example is the behavior in the United States of the discount on the Germany fund. During the winter of 1989-1990, after the fall of the Berlin Wall, the typical discount of 10 percent turned into a premium of 100 percent. Hardouvelis et al. attributed this dramatic rise to speculation about investment opportunities in Germany. The Germany fund traded at a premium for a long time after this episode, and by April 1990, three more German closed-end funds had come into existence-at which point, the premium evaporated.

What made this behavior most puzzling is that it seemed to carry a crossborder contagion. Other country funds (e.g., the Austria, First Iberia, Italy, Swiss, Malaysia, Thai, and Taiwan funds) experienced dramatic but shortlived discount decreases or premium increases over the same period. Moreover, such episodes occur relatively frequently; notable examples from the 1990s are the First Israel Fund,23 which traded first at a deep discount and then at a high premium during the 1993-94 period, and the Turkish Investment Fund,24 whose NAV dropped drastically in early 1994 while the fund's premium rose sharply.

Zweig (1973) was the first to suggest that discounts might reflect the expectations of individual investors. Weiss (1989) supported this conjecture and showed that individual investors owned a larger stake in closed-end funds

23The First Israel Fund traded at a deep discount during the period from April 1993 to August 1993. From mid-January 1994 to November 1994, however, First Israel traded at sharp premiums, often as high as 25 percent. One factor that might explain this dramatic reversal in market perception could be the peace settlements between Israel and its neighbors following the Oslo accords of September 1993.

24The Turkish Investment Fund traded at close to its NAV from September 1993 to January 1994. Starting in late January, the NAV sank precipitously-a drop of more than 70 percentuntil April 1994. The NAV was mirroring a similar drop in the dollar-adjusted Turkish stock market, which was in considerable turmoil during that period. Oddly enough, the market price of the fund did not fall as steeply - a drop of 49 percent during the same period. Consequently, premiums increased dramatically, even reaching 100 percent on one occasion. 
than did institutional investors. 25 Building on this evidence, LST speculated that the discount movements may reflect the differential sentiment of individual investors because these investors hold and trade a preponderance of closed-end fund shares but are not as important an ownership group in the assets of the fund's portfolio.

De Long, Shleifer, Summers, and Waldmann (1990) and LST explored a possible explanation of the closed-end fund puzzle based on a model of noise trading, which contradicts the efficient market hypothesis. The argument is that discounts on closed-end funds reflect changes in investor sentiment rather than changes in each fund's management. These authors suggested the existence of two kinds of investors-rational investors and irrational investors ("noise traders"). The rational investors have unbiased expectations, whereas the irrational investors make systematic forecasting errors. The argument rests on three important assumptions: (1) Rational investors are risk averse, (2) rational investors have finite horizons, and (3) fluctuations in noise trader sentiment affect many assets and are correlated across noise traders, which implies that the risk these fluctuations create cannot be diversified away.

The intuition driving this approach is that fluctuations in noise trader sentiment are unpredictable. This noise trader risk explains why arbitrageurs do not keep prices close to fundamental values (NAVs). Noise trader risk deters rational investors from attempting aggressive arbitrage strategies, and therefore, on average, closed-end funds trade at a discount. Thus, evidence that funds, on average, sell at below NAV does not rely on the average pessimism of noise traders but stems completely from the risk aversion of rational investors, who are willing to buy closed-end fund shares only if they are compensated for noise trader risk. In other words, rational investors will buy a fund only if it trades at a discount.

Like fundamental risk, noise trader risk will be priced in equilibrium because it cannot be diversified away. As a result, assets subject to noise trader risk will earn a higher expected return than assets not subject to such risk. Relative to their fundamental values, these assets will be underpriced. The returns earned by the portfolio strategies in Thompson's work, for example, were earned at the expense of being exposed to investor sentiment.

25Weiss compared the relative level of institutional ownership for closed-end fund IPOs and a control sample of 59 equity IPOs. Institutional ownership of equity is significantly higher for the control sample of IPOs than for closed-end funds (respectively, 21.8 percent and 3.5 percent) after the first quarter following the offering, and the disparity of levels persists throughout the next two quarters. 
LST showed that the implications derived from the investor sentiment theory are supported by U.S. empirical findings. In the following subsections, we discuss each body of evidence in turn.

Individual Investors. Behavioral explanations for the closed-end fund discount emphasize the behavior of individual investors. They may at times be particularly enthusiastic about stock market investing, and this enthusiasm is likely to coincide with buying pressure for stocks that capture their attention, for mutual funds, and for securities that have high exposure to equity market fluctuations. The evidence is broadly consistent with these conjectures.

LST posited that institutional investors tend to shy away from closed-end funds, presumably because they are money managers themselves who are reluctant to delegate money management, which results in a higher concentration of individual investors in a fund than in the fund's underlying assets. To the extent that individual investors are more prone to investor sentiment, a discount arises to compensate for the noise trader risk.

Grullon and Wang (2001) took a different approach to examining the effect of the institutional ownership differential. They suggested that institutional and individual investors can also differ in their abilities to access and/or process relevant information about the assets in which they invest. In this regard, institutional investors have an incentive to concentrate their investments in underlying assets, rather than in a fund, to exploit their informational advantage over individual investors. Grullon and Wang developed a multiasset trading model with an emphasis on asymmetrical information to examine the closed-end fund discount. The model showed that a larger informed ownership in the underlying assets than in the fund can generate the discount. In particular, they found the discount to be positively related to the quality of private information in the underlying assets. The discount reflects, therefore, a differential risk perception between informed and uninformed traders.

Sias (1997) investigated whether individual and institutional investors respond differently to changes in market conditions. Closed-end funds are the medium to test the hypothesis because shares in closed-end funds (held primarily by individual investors) and shares in the underlying assets (held primarily by institutional investors) are claims on the same stream of distributions. The empirical results suggest that individual investors are more responsive than institutional investors to changes in market conditions. Thus, a change in market conditions generally results in a larger change in fund share prices than the value of the underlying assets. The results are consistent with a special case of the investor sentiment hypothesis presented by De Long, et al. in which the irrational behavior of individual investors manifests itself as overreaction to changes in economic conditions. 
Elton, Gruber, and Busse (1998) explored whether sentiment, as measured by the change in the discounts on closed-end funds, is an important factor in the return-generating process of common stocks. They found no evidence in either common stocks or closed-end funds to support smallinvestor sentiment as a priced factor.

Small-firm effect. LST conjectured that the argument based on individual-investor sentiment explains both the behavior of the discount on closed-end funds and the performance of small-cap stocks in relation to the performance of large-cap stocks. Individual investors hold small-cap stocks disproportionately more than institutional investors, so the small-stock premium is an indicator of investor sentiment. LST's results support this theory because they found that discounts tend to narrow when small-cap stocks perform well and vice versa. In a similar vein, Brauer and Chang (1990) showed that the prices of U.S. closed-end funds display a typical size-related January effect whereas their NAVs do not. 26 The return on the common stock of large closed-end funds over the first four weeks of the year exceeds the average four-week rate of return over the rest of the year by 3.4 percentage points (pps). The common stock of small-closed-end funds earns almost twice this differential, 6.7 pps.

Evidence for the U.K. market does not seem to confirm those results. Dimson and Minio-Paluello (2002) found for U.K. funds during January 1980 through March 1997 that both share price and NAV returns are characterized by turn-of-the-year seasonality. As Table $\mathbf{3}$ shows, January returns are significantly higher than non-January returns. They also found that, on average, the discount decreases (the logarithm of the price-to-NAV ratio increases) during the month of January. However, the average first differences-namely, the month-to-month changes in the discount-are not significantly different in January from the rest of the year. As noted in Dimson, Marsh, and Staunton (2002), stock market patterns often fail to migrate across the Atlantic. In this case, unlike in the United States, the U.K. closed-end fund discount does not seem to be characterized by a January effect.

Chen, Kan, and Miller (1993) challenged the investor-sentiment theory by questioning the link between discounts and the return premium on small companies. They argued that the time period tested-and not institutional ownership-matters for the results previously found. Chopra, Lee, Shleifer, and Thaler (1993) responded by providing additional tests of the robustness of the relationship between the discounts and type of ownership. Following these results, Chen, Kan, and Miller pointed out that the covariation between closedend fund discounts and size-based returns is no more than a trivial 4 percent.

26Exceptional returns of small-cap stocks during January were first reported for the 1963-79 period; although smaller in recent years, this effect has persisted. 


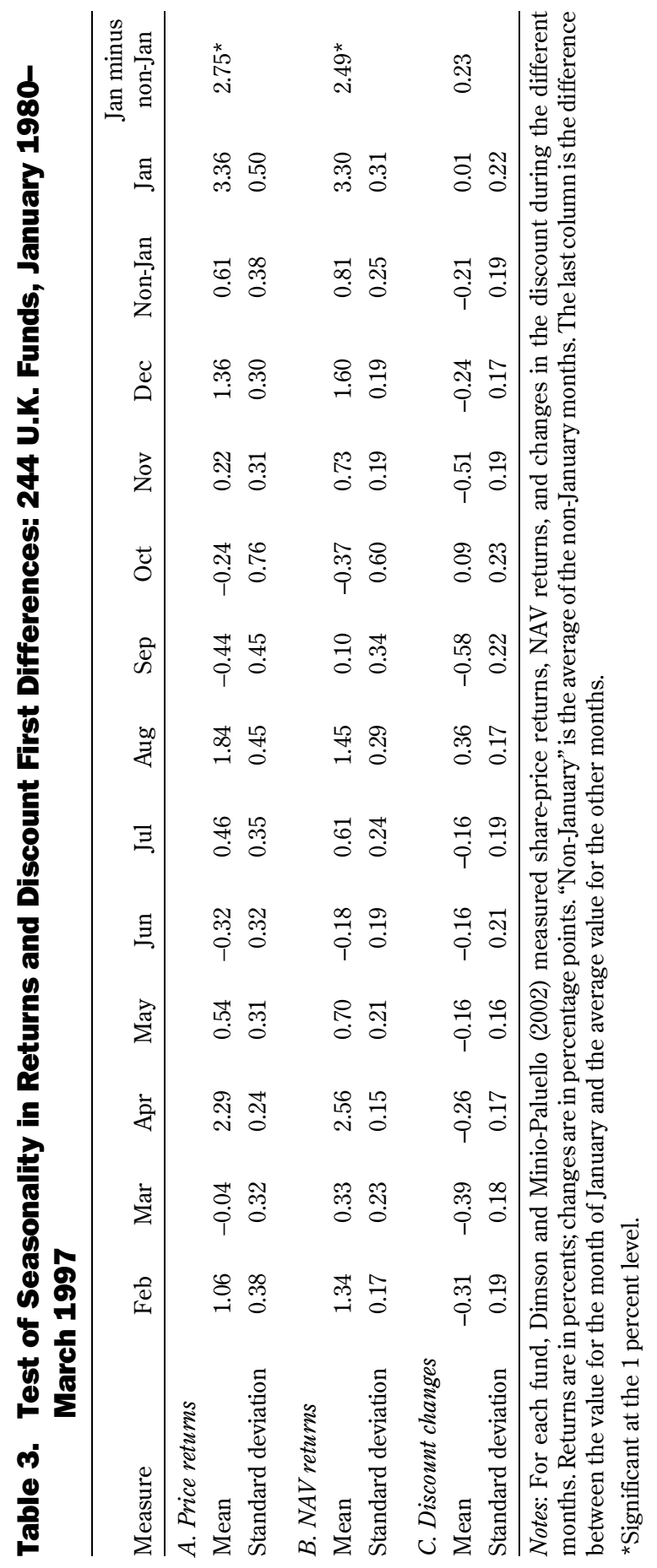


To summarize, the key issues in this debate are the statistical and economic significance of the correlation between changes in the discounts on closed-end funds and excess returns on small stocks, as measured by incremental $R^{2}$. Chopra et al. argued that with an $R^{2}$ of about 7-9 percent, the investor-sentiment index explains small-firm excess returns at least as well as the "fundamental" APT (arbitrage pricing theory) factors used by Chen, Roll, and Ross (1986).

Swaminathan (1996) further investigated investor sentiment and the contemporaneous correlation between closed-end fund discounts and small-firm returns. He recognized that (mean-reverting) individual-investor sentiment should not only affect current stock prices but also forecast future stock returns. The idea is that individual investors' optimism pushes current stock prices above fundamentals, causing current returns to be high. Then, as these temporary deviations are corrected, stock prices fall and revert to fundamentals, which causes future returns to be low. The empirical tests produce reliable evidence that discounts forecast small-firm returns better than they forecast large-firm returns. Moreover, the forecasting power of discounts is independent of the movements tracked by other predictive variables, such as the dividend yield, the default spread, and the term spread. 27

Neal and Wheatley (1998b) examined the power of three popular measures of investor sentiment to predict returns: the level of discounts on closedend funds, the ratio of odd-lot sales to purchase, and net mutual fund redemptions. Using data from 1933 to 1993 , they found that discounts and net redemptions predict the size premium - the difference between small- and large-firm returns-but found little indication that the odd-lot ratio predicts returns.

Short-sale constraints and illiquidity. An expanding body of behavioral finance is focusing on the pricing of securities that experience constraints in the way they are traded. A number of these securities behave like closed-end funds, and this provides further evidence that is consistent with the investor sentiment hypothesis. Barber (1994) suggested that noise trading drives the time-series variation of the premium of "primes" and "scores" on the Dow Jones 30.28 A prime entitles an investor to all cash distributions on the stock

27The default spread is a measure of the default risk premium in the economy and is defined as the difference between the yield on a portfolio of low-grade corporate bonds and the yield on a portfolio of high-grade corporate bonds. The term spread is a measure of the term risk premium in the economy and is defined as the difference between the yield on a portfolio of high-grade bonds and the short-term interest rate.

28 Separation of returns into primes and scores was an innovation of the Americus Fund, which offered investors the opportunity to tender Dow 30 constituents in exchange for a prime and a score. 
and a preset proportion of the market value of the security at a specified future date up to a present amount (that is, the termination value); a score entitles the investor to the stock's capital appreciation above the specified termination claim. Despite the fact that a combined prime and score provide the same cash flows as the common stock, these securities trade at an average 1 percent premium over the price of the underlying asset. Barber showed that primes and scores are predominantly traded by individuals, that the levels and changes of their premiums are correlated across funds, and that changes in their premiums are correlated with the changes in the discount of closed-end funds as well as with small-firm returns-all three of which are constrained from perfect arbitrage because of limits on short selling.

When funds trade at less than NAV and investors wish to arbitrage the discount, they must short the assets of the fund and go long the common stock of the fund. If investors suffer limitations in their capacity to go short, then arbitrage is curtailed. Short-sale constraints, within the market as a whole, are thus a key factor in limiting arbitrage among closed-end funds that trade at a discount. Similarly, when funds trade at a premium, arbitrage involves taking a short position in the common stock of the fund, and constraints on shorting fund shares can allow a premium to persist.

Several researchers have investigated the effect of short-sale constraints on security prices. For example, Lamont and Thaler (forthcoming 2003) examined a sample of technology "carve-outs" that appeared to be overpriced and that were constrained from reverting to their appropriate price level by limitations on short selling. Chen, Hong, and Stein (2002) and Jones and Lamont (2002) showed that when stocks are difficult or expensive to short, fund prices can deviate persistently from fundamental values. Such research supports the argument that apparent mispricing may persist without obvious opportunities for implementing trading strategies that could bring prices back into line with fundamentals. Indeed, most empiricists working in this area generally interpret their results in the context of the limits to arbitrage propounded by Pontiff (1996) and Shleifer and Vishny (1997).

In a similar manner, illiquidity or relative marketability of an asset may play a role in security pricing. An example is bonds linked to an equity index; these bonds have coupons and principal payments that replicate the income and capital payoffs from holding a common stock index. In contrast to index funds and exchange-traded funds, the payoff of an equity-index-linked bond is not attenuated by costs or fees. Despite this advantage, these bonds trade at a discount to the underlying index. Dimson and Hanke (2002) attributed this discount to the impaired liquidity of these securities compared with the underlying index portfolio. They found that the premium on equity-linked bonds varies with the closed-end fund discount, the small-cap premium, and several other proxies for the illiquidity premium. 
Net redemption. Malkiel and LST provided additional evidence supporting the view that changes in closed-end fund discounts reflect changes in individual-investor sentiment by showing that discounts tend to increase with net redemptions in the units of open-end funds. This finding, although the regression coefficient is not significant, suggests that investors in openend funds, who are mainly individuals, are affected by the same fluctuations in sentiment as closed-end fund investors. Furthermore, discounts do not seem to be highly correlated with measures of fundamental risk, which implies that this sentiment index is not a proxy for macroeconomics factors previously identified by Chen, Roll, and Ross and by others.

Despite the fact that U.S. closed-end funds are held primarily by individuals whereas U.K. closed-end funds are held mainly by institutions, Levis and Thomas (2000) and Bleaney (2002) also found a relationship between individual-investor money flowing into U.K. mutual funds and a narrowing in the discount of U.K.-traded closed-end funds.

The evidence that there is a link between discounts and individual investors' activity-but not institutional investors' activity-is consistent with the investor-sentiment hypothesis.

New Issues. Consistent with the implications of the De Long et al. noise trader model, Levis and Thomas (1995) showed that U.K. closed-end fund IPOs are subject to "hot issue periods"; that is, IPOs tend to occur when a marked narrowing occurs in the discounts of seasoned funds. Additionally, Levis and Thomas (2000) showed that new country funds, both in the United Kingdom and United States, are launched when seasoned country funds are selling at a premium or at historically low levels of discounts. Levis and Thomas also found evidence in the U.K. data that individual investors' money tends to flow into U.K. mutual funds at the same time that discounts of U.K.traded country funds narrow.

Similarly, Burch and Weiss Hanley (1996) suggested that closed-end fund managers choose the timing of secondary offerings to coincide with periods of high demand and with intervals when funds trade at a premium.

The fact that closed-end funds are characterized by a substantial price decline after flotation cannot explain the behavior, however, of investors who buy in the first place. Weiss Hanley, Lee, and Seguin (1996) attempted to explain this anomaly by examining aftermarket transactions for closed-end fund IPOs. They showed that most closed-end fund trading in the initial weeks is seller initiated, 29 that there is evidence of intense price stabilization, and

29 Short selling is not allowed during the first weeks of trading. Therefore, Weiss Hanley et al. related this selling pressure to the presence of "flippers"-investors who buy IPOs during the pre-issue period and immediately resell them in the aftermarket. 
finally, that a significantly higher proportion of the sells (buys) in the first 30 days are initiated by large (small) traders. These findings suggest that closedend fund IPOs are sold by professionals to less informed (irrational or noise) investors. This "marketing" hypothesis is consistent with U.S. evidence that only individual investors hold these shares in the long run but not with the evidence of predominantly institutional ownership observed in the United Kingdom (Ammer).

Fluctuations in the Discount. One of the implications of the investorsentiment theory is that discounts on various funds will tend to move together. LST showed that the average pairwise correlation of annual changes in discounts among U.S.-domestic stock funds over the 1965-85 period is 0.39 . Similarly, Minio-Paluello (1998) found for the U.K. market an average correlation of 0.30 between the changes in the discount of all pairs of funds in the "international general" category of closed-end funds (see Table 2). Cointegration analysis, a more robust specification of the comovement in discounts than pairwise correlation, shows that discounts of funds in the same category tend to move together. Minio-Paluello also demonstrated that the average discounts of the different categories are co-integrated, as shown in Table 4. Consistent with this finding, Adams (2000) found evidence of a systematic inverse correlation between discounts and NAV movements.

LST speculated that the discount movements reflect individual investors' sentiment. However, using closed-end funds whose NAVs are determined in the same market as the constituent share prices (domestic funds) does not capture all the marketwide sentiment. Bodurtha et al. investigated an extended form of the investor-sentiment hypothesis using closed-end country funds. They found that stock prices of country funds move together with U.S. market returns but changes in their NAVs do not. Bodurtha et al. also showed that premiums on country funds tend to move together but not with those of domestic closed-end fund premiums.

The investor-sentiment hypothesis finds interesting support in the international market. Empirical evidence on the behavior of country funds shows that discounts can be used to predict the future prices of the funds but not of the underlying assets. This finding suggests that fund prices are driven by factors other than the assets' values. Moreover, this predictability seems linked to changes in worldwide and U.S. stock returns, not to changes in individual countries.

For the United Kingdom, Cheng, Copeland, and O'Hanlon (1994) confirmed the Brickley et al. finding that U.S. discounts tend to narrow as the market rises and widen as it declines. This empirical regularity suggests the existence of some overreaction in the pricing of closed-end fund shares. 


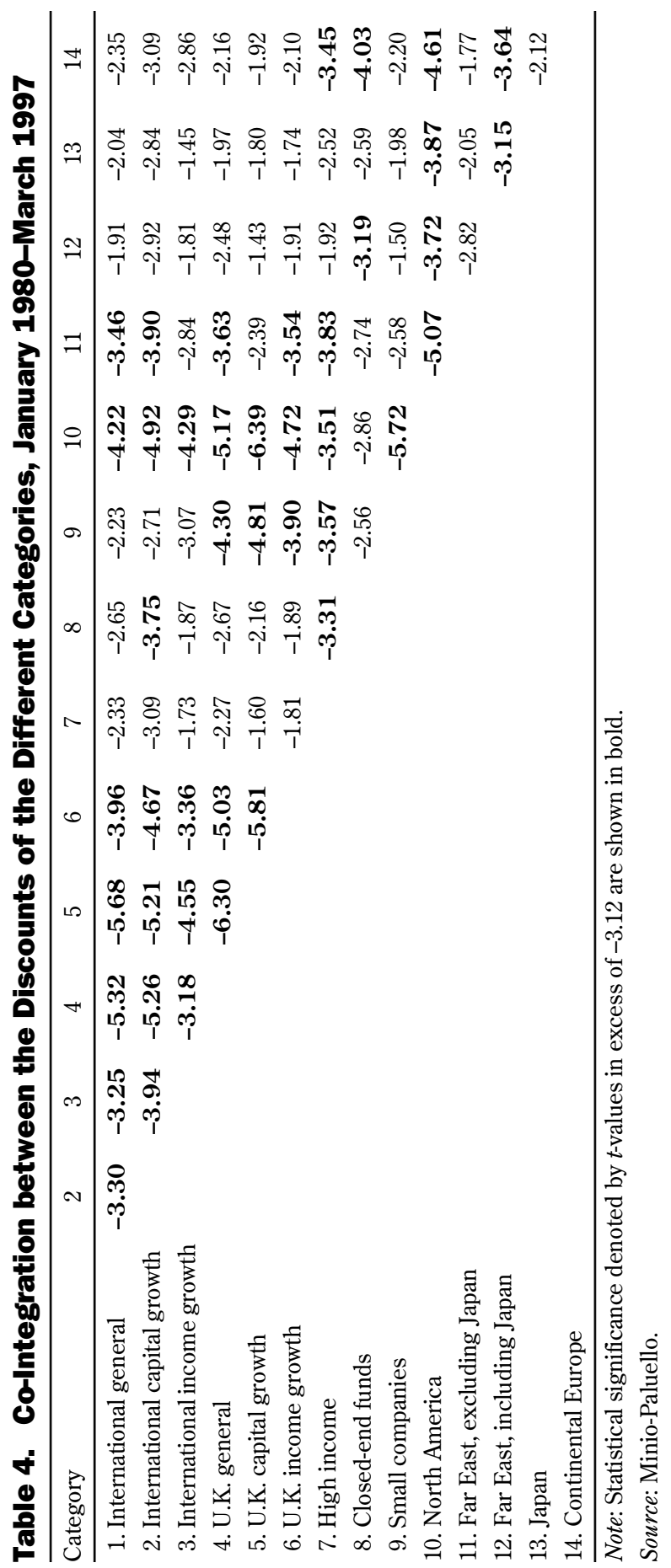


Nevertheless, Minio-Paluello found no relationship between changes in U.K. discounts and the returns on the Financial Times Stock Exchange (FTSE) 100 Index.

\section{Conclusions and Limitations of Investor-Sentiment Theories.}

The investor sentiment hypothesis provides an interesting explanation of the closed-end fund discount puzzle. In particular, the findings of this research indicate that (1) new funds are started when seasoned funds sell at a premium or at a small discount; (2) discounts are correlated with prices of other securities, such as small-cap stocks, which are affected by the same investor sentiment; and (3) discounts on various funds move together. Some articles, however, do not confirm this hypothesis. For example, Abraham, Elan, and Marcus (1993) used the comparative performance of bond versus stock funds to examine the sentiment hypothesis and found that discounts on bond funds exhibit a systematic risk (the beta of the discount) almost as large as that on stock funds, despite the fact that bond funds hold assets whose values are far less subject to fluctuations of individual investors' sentiments. Furthermore, despite the similar level of systematic risk, bond funds, on average, do not trade at large discounts. In the $1985-89$ period, the 120 bond funds traded at an average premium of 1.1 percent. In contrast, the 71 equity funds traded at a discount of 6.1 percent.

Even more contradictory is Ammer's evidence on U.K. closed-end fund expenses, yields, and excess returns. The limited rationality theory is grounded on the observation that individual investors own the largest stake of U.S. closed-end funds. However, despite the fact that U.K. closed-end funds go through periods of discounts and premiums similar in most respect to U.S. funds, their clientele is, and for more than a decade has been, largely institutional. The proportion of closed-end fund shares held by institutions in the United Kingdom was 70-75 percent in 1990, and Warburg Securities (19881990) reported that only 7 out of 102 funds had more than half of their shares registered to individuals (see also Lofthouse 1999). 30

Although the limits-to-arbitrage approach can potentially explain discounts as a rational response to noise trading, other researchers have come up with alternative stories to explain the discount. For example, Spiegel (1999)

\footnotetext{
30Draper estimated that in the late 1960s, individual investors held, on average, 75 percent of the capitalization of his sample of leading closed-end funds. By 1986, the proportion held by individuals had fallen to 22 percent (Brown 1998). Warburg Securities reported that institutions held some three-quarters of the shares issued by U.K. closed-end funds. Andrei Shleifer suggested to us in private correspondence that the discount should be related to the sentiment of the dominant investor group. When the balance of ownership shifts over time, as in the United Kingdom, applying the insights of LST is harder.
} 
noted that in a frictionless market, finite-lived agents might be able to determine equilibrium prices that deviate systematically from NAV. Other writers (for instance, Bhattacharyya and Nanda 1999) invoked inventory risk to provide a rational explanation of discounts. And new theoretical frameworks continue to be developed (see, for example, Arora and Ou-Yang 2002).

Financial economists mostly regard the noise trader hypothesis with some skepticism, yet they concede that more research is undoubtedly required. No existing theories of asset pricing are able to explain fully the empirical observations documented by LST. If the behavior of the discount reflects investor sentiment and does not conform to rational models of asset pricing, then opportunities may exist for investors to exploit errors in the pricing of closed-end funds. In the next section, we survey studies that provide insights into these apparent opportunities.

\section{Exploiting the Discount}

Several studies have shown that abnormal returns can be earned by following simple trading strategies based on the level of recent movements of the discount. Doubt remains, however, as to whether the existence and behavior of discounts is evidence of persistent mispricing of assets because of market inefficiencies. In most cases, tests of potential mispricing are joint tests of market efficiency and an equilibrium model of asset pricing, and deciding what model is appropriate for the pricing of closed-end funds raises particular difficulties. It is not clear whether there is a risk-adjusted reward from buying when the stock price is attractively low and/or selling when the stock price appears excessive. An alternative means of releasing the underlying NAV of a closed-end fund is through corporate acquisition, but unless the acquirer's bid is at NAV, which leaves little profit for the bidder, shareholders have little incentive to agree to a takeover (Grossman and Hart 1980).31

Clearly, seeking to exploit apparent mispricing and arbitrage opportunities has potential problems. We review the evidence that supports the case for trading in the shares of closed-end funds and appraise the opportunities for profitable trading. We, therefore, turn first to the abnormal returns available at the time of the IPO. We then describe potential arbitrage opportunities based on the mean-reverting character of the discount and on the behavior of the fund at open-ending. We also present illustrations of the design and behavior of a mimicking portfolio.

31 Nevertheless, takeover activity within the closed-end fund sector has increased. And in the United Kingdom, closed-end funds have been experiencing corporate activity at an unprecedented rate over the last five years. 
Initial Public Offerings. The level of efficiency or inefficiency in the closed-end fund market can be measured by the presence of short-term arbitrage opportunities. Peavy (1990) and Weiss documented the gradual decline in the value of newly issued shares over the first 100 trading days after an IPO. If this gradual decline in value reflects market inefficiency, then investors could take advantage of the mispricing by short selling the securities.

Weiss Hanley and Seyhun (1994) investigated the profitability of arbitrage and provided evidence of closed-end fund pricing inefficiency at the time of an IPO. They showed that short sellers are interested in funds trading at a premium, but their profitability is limited to the early months of the IPO. $32 \mathrm{On}$ average, short sellers could earn a significant abnormal return of 21 percent after 150 trading days. Incentives to sell closed-end fund IPOs short are thus great. Note, however, that LST reported conversations with traders who said that they found executing short sales of closed-end fund IPOs very difficult, so this opportunity may be available only sporadically and to a limited number of market participants.

Levis and Thomas (1995) argued that U.K. closed-end fund IPOs disclose an aftermarket performance similar to that observed for industrial IPOs. As depicted in Figure 2, the results show that the long-run underperformance of U.K. closed-end funds is smaller than that of U.S. funds. ${ }^{33}$ Larger institutional ownership in the United Kingdom is suggested as a possible explanation. Levis and Thomas did not document the extent to which short-sale profits could actually be achieved in U.K. market IPOs, but practitioners, as well as researchers (such as Bangassa 2000), regard this strategy as difficult to implement.

Khurshed and Mudambi (2001) investigated the performance of U.K. investment trusts as a test of the Rock (1986) model of IPO short-run underpricing. The Rock model implies that there should be significant underpricing in the IPOs of conventional issuing companies but little or none in the case of investment trust IPOs. The characteristics of investment trusts are such that the scope for creating an information advantage is smaller for investment trusts than for conventional issuing companies. Typically, investment trusts have no business history before the offering; the bulk of their assets are securities that are frequently traded and whose prices are publicly quoted, and they have a fixed stock of capital out of which they must pay for all costs

32Short sellers are unable to take immediate advantage of the overpricing in closed-end fund IPOs because physical delivery of the securities does not occur until after the distribution is completed (at least 7-10 days later).

33 Weiss found an abnormal performance of -23.2 percent for domestic equity funds after the first 120 trading days. For U.K. closed-end funds, Levis and Thomas (1995) found a value of -5.3 percent. 


\section{Figure 2. Average Discount during the First Months of Trading}

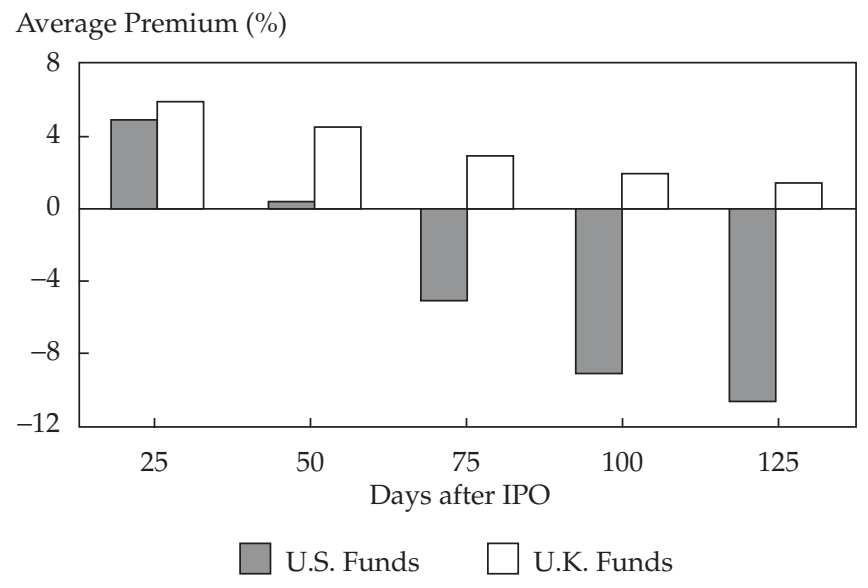

Notes: U.S. funds as measured by Weiss (1989) for 22 U.S. equity closed-end fund IPOs during the 1985-87 period; U.K. funds as measured by Levis and Thomas (1995) for 73 closed-end funds issued between 1984 and 1992.

involved with the issue. Khurshed and Mudambi argued that the information asymmetry should be minimal in the case of investment trusts but significant in the case of conventional issuing companies. Their findings provided strong evidence in favor of the Rock model.

It is interesting to note that issues of closed-end fund rights have some similarities with closed-end fund IPOs. Khorana, Wahal, and Zenner (2002) studied 120 rights offerings by U.S. closed-end funds over the 1988-98 period and found that, on average, rights offerings are announced when funds trade at a premium and that this premium turns into a discount over the course of the offering. The evidence also suggests that the premium decline is larger when investment advisors' compensation is larger and when the fund uses affiliated broker/dealers to solicit subscriptions to the offer. The results imply the existence of significant conflicts of interests in rights offerings by closedend funds. A similar study by Higgins, Howton, and Howton (forthcoming 2003) of 105 closed-end seasoned equity offerings during 1980-1997 concluded that managers time issues to take advantage of mean reversion in fund performance.

Mean Reversion. One of the most influential papers on exploiting the closed-end fund discount is Thompson's 1978 article. Thompson documented 
the empirical regularity that U.S. closed-end funds trading at a substantial discount accrue positive abnormal returns, and those trading at a premium (or at a narrow discount) accrue negative abnormal returns. Thompson measured the returns from trading strategies based on the level of the discount over the $1940-75$ period.

Table 5 documents the results of the various strategies considered by Thompson. The discount-based strategies, investing in funds selling at a discount, achieved positive and significant mean abnormal returns. The strategy of investing in funds that were selling at a premium accrued a highly negative, but not statistically significant, abnormal return. The rules Thompson tested are relatively simple discount-based trading rules, which, he observed, are unlikely to have used all of the information contained in the discounts, yet he still found positive abnormal returns for the discount strategies. These results can be interpreted as high discounts being an indicator of underpricing, which, because the market does not recognize this underpricing, imply an inefficient market.

\section{Table 5. Returns to 23 Discount-Based Trading Strategies, January 1940-December 1975}

\begin{tabular}{lc}
\hline Strategy & Abnormal Return \\
\hline Discount weighted & $4.12 \%$ \\
Discount—equal weights & 2.37 \\
Premium & -7.97 \\
All funds & 0.54 \\
\hline
\end{tabular}

Notes: The "Discount weighted" strategy invested in funds trading at a discount at the beginning of each year; weights were set proportional to the size of the discount at the beginning of the year. The "Discount-equal weights" strategy held the identical securities as the discount-weighted strategy, but the weights were set identical across funds. The "Premium" strategy invested in funds trading at a premium at the beginning of each year; weights were set identical across funds. The "All funds" strategy served as a control; at the beginning of each year, an equal investment was made in every fund in the sample.

Source: Thompson.

Thompson was careful to emphasize that it is not possible to identify the extent to which his results reflect capital market inefficiency, as opposed to deficiencies in the method of adjusting prices for risk. ${ }^{34}$ Evidence from an

34Thompson argued that the abnormal returns are likely to have been caused by inadequacies of the asset-pricing model, not market inefficiency, because the data on closed-end fund discounts were widely available over the entire period and extensively discussed in the professional press. 
earlier study by Zweig, however, also suggests a marked investment opportunity. Furthermore, Anderson (1986) reported evidence that abnormal returns could be earned by using filter rules for the purchase of the shares of closedend funds whose discounts had widened and the sale of the shares of companies of whose discounts had narrowed. And more recently, Kellerhals and Schöbel (2002) reported on a filter rule applied to country funds over a brief interval (1993-1997) with some evidence of out-of-sample predictability.

Pontiff (1995) provided further evidence showing that U.S. discounts have an economically strong ability to predict returns that cannot be explained by other factors that affect expected returns, such as multifactor risk exposure, bid-offer spreads, dividends, and varying risk exposures. Pontiff attributed the correlation between fund discounts and future returns to mean reversion of the discount, not to anticipated future NAV performance. He found that funds with a discount of 20 percent have expected one-year returns that are 6 percent higher than nondiscounted funds.

Evidence from U.K. closed-end funds has until recently been less comprehensive and less compelling. The investment performance study of Guy (1978) suggested that U.K. closed-end fund shares do not outperform the market after suitable allowance for risk. Whiting (1984), however, using models based on the level of the discount, found evidence of profitable trading opportunities in U.K. closed-end funds. Cheng et al. tested for evidence that abnormal returns can be earned by holding closed-end fund shares in accordance with a simple discount-based strategy. The results are not strong enough to imply that positive abnormal returns are possible in round-trip trading strategies, but substantial returns would be available to a strategy of selling one's existing holding of low-discount closed-end funds and replacing it with high-discount closed-end funds. 35 Cheng et al. found positive and negative abnormal returns to be associated with, respectively, high- and lowdiscount closed-end funds. Fraser and Power (1992) provided further evidence of market inefficiency in the U.K. closed-end fund market. They found significant autocorrelation in the excess returns on shares in U.K. closed-end funds, which indicates the predictability of those returns.

The performance of small- and large-discount portfolios is a first indication of the importance of mean reversion in the discounts. Minio-Paluello analyzed a sample of 244 U.K. closed-end funds for the period January 1980 through March 1997. She allocated funds to deciles based on fund discounts on each

35 Returns were computed from monthly prices of closed-end fund shares without adjusting for the bid-ask spread. The typical spread on U.K. closed-end funds is lower than 2 percent, however, which is well below the estimated abnormal return of 3-5 percent on high-discount portfolios. 
of 35 semiannual ranking dates. Each ranking was based on the universe of funds that had a listing at the ranking date, and to avoid bias, the deciles were constructed one month after the ranking took place. Figure 3 shows the behavior of the discounts of the small-discount portfolio (Decile 1), the largediscount portfolio (Decile 10), and an arbitrage portfolio (which was long in the large-discount decile and short in the small-discount decile). Note the tendency for discounts to revert to their mean. That is, the discount of Decile 1 tended to widen, whereas the discount of Decile 10 tended to narrow. The discount on the arbitrage portfolio shows a significant trend; on average, it decreased over an interval of one year from 30 percent to 20 percent. 36 The implications are that, as in Sias, Starks, and Tinic (2001), discounts mean revert and there is potential for generating positive returns. Keep in mind, however, that risk adjustment and transaction costs considerably attenuate the potential gain depicted in Figure 3.

\title{
Figure 3. Mean Reversion of Top and Bottom Decile Portfolios of U.K. Funds, January 1980-March 1997
}

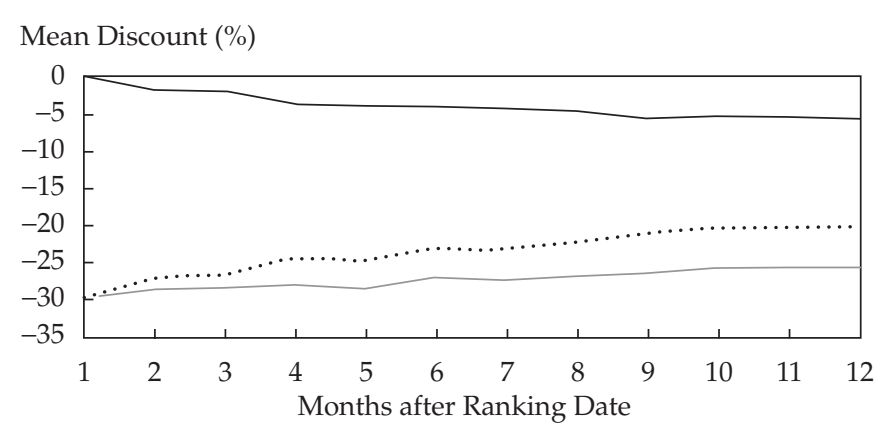

Discount of Decile 1 Discount of Decile 10

Discount of Decile 10 - Discount of Decile 1

\begin{abstract}
Notes: Average from the 35 rankings of the portfolios' discount measured over one-year periods; portfolios constructed one month after the ranking. The portfolio discount, defined as the logarithm of the equally weighted average of price-to-NAV ratios, was measured over a one-year period.
\end{abstract}

Source: Minio-Paluello.

\footnotetext{
36The average result from all the rankings shows that the discount of Decile 1 narrowed by 4 pps and the discount of Decile 10 widened by 6 pps. The decrease for the small-discount portfolio partly reflects the fact that new funds are launched at a premium to NAV, which moves to a discount within a short period.
} 
Cakici, Tessitore, and Usmen (2000) examined whether discounts and premiums on closed-end funds can be used to earn positive excess returns over a benchmark index. Consistent with Thompson, they found that long portfolios of closed-end fund shares trading at a discount outperform a benchmark index. Cakici et al. introduced transaction costs and compared the excess return generated by long portfolios with deep discounts with the excess return of short portfolios with deep premiums. They found that short portfolios of closed-end funds trading with deep premiums can be more profitable than long portfolios trading with deep discounts. This result arises because portfolios built around premiums evolve more slowly and, hence, have a lower turnover. Lower turnover makes a difference when transaction costs are moderate to high, which is the norm with closed-end funds.

Cakici, Tessitore, and Usmen (2002) examined investments in closed-end equity funds in an environment of transaction costs and practical constraints on portfolio selection. This study showed that portfolios with frequent rebalancing and loose constraints on turnover outperform a benchmark index, provided that transaction costs are low. They also found, in contrast, that portfolios with less-frequent rebalancing and more-stringent restrictions on turnover outperform the benchmark index when transaction costs are high.

Mimicking Portfolios. One of the difficulties of arbitrage is identifying the positions that perform best as a hedge for fluctuations in the NAV of a potentially mispriced fund. Dimson and Minio-Paluello (2001) used Sharpe's (1992) returns-based style analysis to infer the effective asset mix from fluctuations in closed-end fund NAV returns. Figure 4 shows the changing effective asset exposure during 1987-1997 of Scottish Investment, a closedend fund in the international general category of closed-end funds. For this fund, the effective asset mix varied gradually over time but was relatively stable. On average, Scottish Investment Trust behaved as though the underlying assets were invested in four equity index portfolios: 23 percent in the U.S. index, 48 percent in the U.K. index, 14 percent in the Europe (ex U.K.) index, and 15 percent in the Pacific Basin index.

For a closed-end fund like Scottish Investment, therefore, an investor could buy the shares and take a short hedging position (e.g., using futures contracts) that mimics fluctuations in the NAV. This strategy would provide pure exposure to the discount overlaid with some noise arising from inaccuracies in estimating the appropriate short positions and the possibility of the manager achieving superior or inferior NAV returns. These elements of noise are diversifiable, so with well-constructed mimicking portfolios, an investor may be able to exploit perceived errors in the level of the discount. 


\section{Figure 4. Mimicking Portfolio for Scottish \\ Investment Trust, 1987-97}

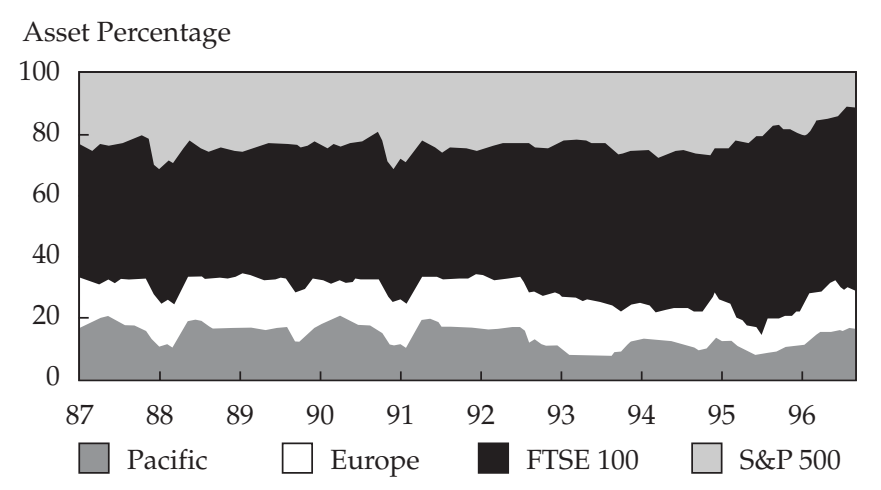

Notes: NAV exposures were estimated by using three-year rolling windows and a set of four indexes: the S\&P 500 Index, FTSE 100 Index, the MSCI International Europe ex UK Index, and the MSCI Pacific (including Japan) Index. The estimated coefficients were constrained to lie between 0 and 100 percent, and the sum of the effective exposures was forced to be 100 percent.

Source: Dimson and Minio-Paluello (2001).

Although many funds have a larger number of effective asset categories, no liquid derivative may be available to offset the NAV exposure of the fund. Nevertheless, Dimson and Minio-Paluello (2001) found that Sharpe's style analysis applied to a sample of 338 U.K. closed-end funds produced an average $R^{2}$ of 0.71 . Of these funds, 70 percent had an $R^{2}$ above 0.75 , and 90 percent had an $R^{2}$ higher than 0.50 . The results show that the Sharpe procedure provides satisfactory estimates of the effective asset mix for a large proportion of closed-end funds. Despite the wide range of investment objectives of British closed-end funds, Sharpe's returns-based style analysis works as well in the United Kingdom as in the United States. 37

If closed-end funds trade at a discount to NAV, shorting the fund's portfolio and holding the fund's shares would seem to create an arbitrage profit. If the discount stays relatively constant over the investment horizon, however, the arbitrageur makes no profit. In the closed-end fund industry, each fund's exposure is normally published weekly or monthly, but the detailed list of all shares held is not necessarily available. Because the exact portfolio composition

37For comparison, Fung and Hsieh (1997) found when using the Sharpe model that 47 percent of U.S. mutual funds have an $R^{2}$ of above 0.75 and 92 percent have an $R^{2}$ higher than 0.50 . 
is not known at every instant, investors must resort to estimates of asset mix, which makes arbitrage both clumsy and potentially costly.

The literature suggests that discounts persist because arbitrage is indeed costly and, therefore, not always profitable. Pontiff (1996) identified factors that influence arbitrage profitability and showed that, cross-sectionally, the magnitude of the discount is most extreme in closed-end funds that hold portfolios with high idiosyncratic risk, in funds with the lowest dividend yield, 38 and in funds with the highest bid-offer spread. In time-series studies, the average magnitude of discounts increased when interest rates rose. 39 Pontiff measured the unhedgeable risk by the volatility of the residuals from regressing NAV returns on a set of asset returns.

Dimson and Minio-Paluello (2001) used a Sharpe style analysis to gain insight into the difficulties of setting up a closed-end arbitrage strategy and the challenge of running an arbitrage position when residual risk can be large. They defined selection returns as the difference between the fund NAV return and the return on a passive portfolio with the same effective asset mix as the fund, and defined the fund's residual risk as the volatility of selection returns. Their results showed that the higher the residual risk, the higher the discount. The conclusion confirms Pontiffs (1996) findings but on a larger and more international sample of funds. 40

Open-Ending. A number of papers have documented the positive abnormal returns possible from U.S. closed-end funds that reorganize to allow shareholders to obtain the market value of the fund's assets. Brauer (1984) noted that a strategy of buying shares on announcement and holding them for three months would have been rewarded with abnormal returns. Brickley and Schallheim (1985) examined the possibility of exploiting the announcement of reorganizations by investing on the last day of the month in which the announcement is made and holding until the fund is reorganized. The result of this strategy was a 15.3 percent average abnormal return, although after adjustments for transaction costs and liquidity premiums during a liquidation, abnormal returns were small.

38Dividends are a benefit for the arbitrageur because for funds with similar discounts, trading the fund with the higher dividend yield will result in speedier convergence of the arbitrage and, hence, larger expected returns.

39 Interest rates are an opportunity cost because arbitrageurs do not enjoy full access to the proceeds of short sales.

40 Pontiff examined 52 domestic U.S. funds that were covered in the Wall Street Journal over the 1965-85 period. Dimson and Minio-Paluello (2001) examined 202 U.K. funds over the 198196 period, a majority of which were invested internationally. 
The existence of abnormal returns after the announcement of openending is inconsistent with the joint hypothesis that the market is efficient and that the market model is the correct return benchmark for funds undertaking reorganizations. The market model may not capture the risks of whether or not the reorganization will take place-the costs of reorganization and the uncertainty about the true NAV. Consequently, the market may price these risks to yield higher expected returns than those given by the benchmark. Also not clear in the research is whether reorganization announcements occurred that were not followed by a restructuring, in which case, the strategy studied in these papers cannot be implemented in reality. The initial response to the announcement suggests that investors in closed-end funds are rational and awake to profit opportunities. Despite the evidence, neither the Brauer (1984) study nor the Brickley and Schallheim study were able to determine whether the closed-end fund market is really inefficient or whether the market model is an inappropriate benchmark.

Brauer (1988) investigated the returns earned during the restructuring of a closed-end fund further-this time focusing on the valuation effects of the potential for open-ending. He found that a trading strategy based on the identification of likely candidates for open-ending, which was governed by both the size of the discount and the management expense ratio, could be profitable. This finding suggests that U.S. closed-end funds' discounts contain information that can be used in a model to predict open-ending activity; from this information, investors could construct portfolios that can earn abnormal returns beyond those earned by the discount-only strategy investigated by Thompson.

For some researchers, evidence of potentially profitable decision rules, together with a failure to explain the discount, has turned market inefficiency into the only possible explanation for the existence and behavior of the discount. If the closed-end fund market is inefficient, then the share price is expected to respond slowly to new information. Brauer (1984) and Draper, however, provided strong evidence supporting the efficient market hypothesis.

Brauer (1984) looked at open-ending events that forced the share price to its NAV. He noted that high-discount companies and companies with lowmanagement expense ratios (as a proxy for managerial resistance to openending) are more likely to open-end. Brauer reported that most of the positive abnormal return associated with open-ending is exhausted by the end of the announcement month. This timely market reaction is consistent with a market for closed-end funds that is generally efficient.

Draper investigated the U.K. closed-end fund industry and found that share prices react rapidly to the announcement of takeovers, open-ending, and 
liquidations. He showed that by the end of the announcement month, all the information about open-ending has been incorporated into the price and no significant rise occurs thereafter. This finding suggests that investors are able to make accurate estimates of the value of a portfolio. Also, in Draper's study, the adjustment in the United Kingdom to the announcement of open-ending appears to be more concentrated and completed more rapidly than in Brauer's U.S. results. Figure 5 shows the patterns of cumulative abnormal returns around the announcement of open-ending for U.K. and U.S. funds.

\section{Figure 5. Abnormal Return Surrounding Open-Ending}

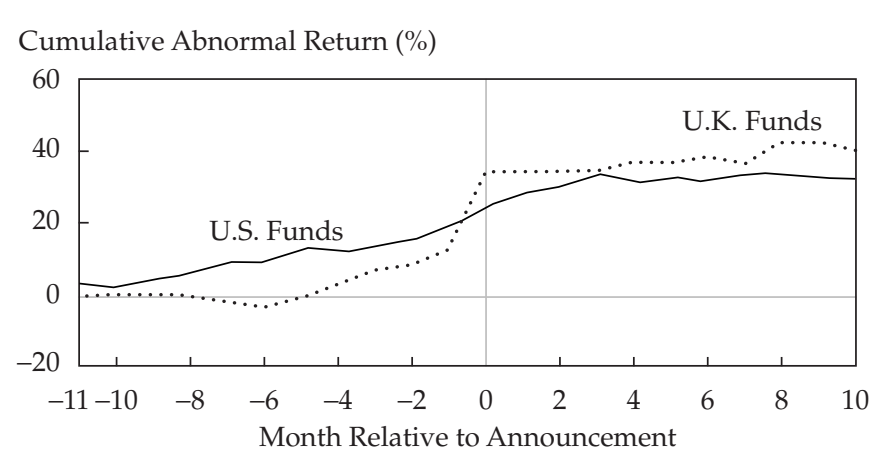

Notes: Cumulative abnormal returns starting from 12 months before the announcement of open-ending to 10 months after the announcement. Brauer (1984) measured the abnormal share price performance of 14 U.S. closed-end funds that open-ended between 1960 and 1981; Draper measured the price reaction to the announcement of open-ending for 40 U.K. closed-end funds over the $1965-83$ period.

Draper provided an additional test of market efficiency by comparing market prices at the time of the announcement of open-ending with the value of the fund's assets at the actual open-ending, adjusted for transaction costs. On average, the difference between the announcement price and the NAV of the funds that liquidated was small. The difference was somewhat larger for the announcements that the closed-end fund was to be converted into an openended structure, but Draper's attempts to derive a profitable decision rule were unsuccessful. Investing in open-ending funds from the day of the announcement to the end of the unitization yielded significant returns only if calculated using raw (unadjusted) market prices. Draper demonstrated that 
considering ask prices adjusted for transaction costs (instead of the unadjusted costs) reduces abnormal returns to levels not even approaching those found by Brickley and Schallheim.

Minio-Paluello described the behavior of U.K. closed-end funds during their last years of trading before open-ending. Based on a sample of 94 funds that open-ended during the period January 1980 to December 1996, she showed that, consistent with the U.S. evidence, share prices rise to NAVs and discounts disappear. The analysis left open the possibility that insiders might have some opportunity to exploit the price behavior of these funds. The market price reacted continuously, however, to the increasing chance of openending from several months before the announcement until a couple of months before open-ending, when the fate of the fund was effectively sealed.

Porter, Roenfeldt, and Sicherman (1999) illustrated the value to shareholders when closed-end funds repurchase shares at a discount from NAV. The greater the discount and the greater the proportion of shares repurchased at the discounted price when the percentage discount does not change after the shares are repurchased, the greater the value.

Discount-Generating Process. The literature describes several characteristics of the behavior of the discount that need to be considered when attempting to explain it. Pontiff (1997), for example, identified four factors that might affect changes in the level of the discount. First, he took into account the Fama and French (1992) factors-fluctuations in the overall market, fluctuations in indexes of stocks classified by the ratio of their book value of equity to market value of equity, and by market capitalization. Pontiff added a fourth factor based on the results of LST: Closed-end funds are subject to systematic "investor sentiment risk" (the tendency of discounts on different funds to move together). In a sample of 52 closed-end funds, Pontiffs four factors explained an average of 15 percent of the fluctuations in the discount to NAV.

In the spirit of Fama and French (1998), who extended domestic evidence on the pricing of common stocks into an international context, Dimson and Minio-Paluello (2002) extended Pontiff's model of the discount-generating process beyond the U.S. market. In examining evidence based on the U.K. market, they chose the world's largest market for closed-end funds and one that also contains many funds that invest globally. In this context, using a few single-country factors to explain the closed-end fund discount is inappropriate. In addition to Pontiff's market, book-to-market, small-firm, and investor-sentiment measures, Dimson and Minio-Paluello attempted to explain at least part of the largely idiosyncratic movements in the discount by introducing other factors: measures of mean reversion, price reversal, past performance, and the impact of the management group on the discount. These factors explained, 
on average, 35 percent of the month-to-month changes in the discount of U.K. closed-end funds. These results indicate that a multifactor model can explain a substantial proportion of the fluctuations in the discount.

\section{Conclusion}

This overview of the literature on closed-end funds has attempted to show the breadth of research on the discount puzzle:

- Investors buy closed-end fund IPOs, despite evidence of a substantial price decline within the first few months.

- Closed-end funds discounts vary cross-sectionally; and discounts fluctuate according to a mean-reverting pattern.

In much of the literature, the emphasis has been on the behavior of U.S. funds, but an increasing volume of research has centered on the U.K. market. The evidence related to the puzzle comes from a number of perspectives and suggests a variety of plausible explanations.

Economic explanations. Several theories about the pricing of closedend funds attempt to make sense of the discount within the framework provided by the efficient market hypothesis.

The first justification for the existence of the discount is that it might reflect overestimated NAVs (i.e., tax liabilities related to unrealized capital gains or differences in liquidity). The literature suggests that part of the level of the discount could be accounted for by biases in the NAV. These explanations are consistent, however, with neither the existence of premiums to NAV nor the empirical regularity of price rises at open-ending.

Second, if management fees are excessive or if managers are expected to underperform, agency costs may explain the existence of the discount on closed-end funds. Agency problems relating to the ownership structure might also explain part of the discount. As we have shown, however, agency theories cannot account for closed-end funds trading or being issued at premiums or for the large fluctuations in the discount.

Third, the tax-timing hypothesis attempts to explain the closed-end fund discount in terms of the loss of valuable tax-trading opportunities associated with the idiosyncratic movements of individual shares, which makes closedend funds attractive to taxable investors. But this theory is inconsistent with evidence that investors' trades are barely motivated by tax considerations.

Fourth, a group of explanations focuses on various forms of market segmentation. By providing a means of overcoming home-country bias, for example, closed-end funds may provide domestic investors with exposure to nondomestic markets. Within domestic markets, the funds may provide exposure to securities whose returns are determined by a different group of 
investors. Another possibility is that funds are priced at a level that reflects private investors' responses to the manager's sales effort or the different valuations institutions and individual investors make. This explanation is confounded by the different ownership patterns but similar discount behavior in the United States and United Kingdom.

In the end, none of these approaches has been able to account for all the anomalies related to the pricing of closed-end funds.

Behavioral explanations. The failure of standard economic theories to explain the anomalous behavior of the discount on closed-end funds casts doubts on the rationality of the market. Therefore, a number of researchers have turned to answers in behavioral finance. Lee, Shleifer, and Thaler (1991), for example, developed a theory that encompasses some aspects of the puzzle in a limited rationality model, which suggests the existence of two kinds of investors-the rational and the irrational. The rational investors have unbiased expectations, whereas the irrational investors (noise traders) make systematic forecasting errors. The argument is that the irrationality of individual investors, the most prominent holders of U.S. closed-end funds, places an additional risk on the assets they trade. LST argued that changes in the discount on closed-end funds thus reflect changes in investors' sentiments. They showed that the implications of the investor-sentiment theory are supported by U.S. evidence. In particular, they found that (1) new funds start when seasoned funds are selling at a premium or at a small discount; (2) discounts are correlated with prices of other securities, such as small stocks, that are affected by the same investor sentiment; and (3) discounts on various funds move together.

Exploiting the discount. Several studies have shown that discountbased strategies can be profitable. The existence and behavior of discounts is not clear evidence, however, of persistent mispricing of assets resulting from market inefficiency. Closed-end fund prices react rapidly to the announcement of open-ending, and no evidence has been presented of profitable arbitrage opportunities, except perhaps during the months following an IPO, when the price decline is substantial.

Many hypotheses have been suggested to explain the discount, but none seem to be able to solve the closed-end fund puzzle. Pontiff (1997) and Dimson and Minio-Paluello (2002) showed that a multifactor model explains a substantial proportion of fluctuations in the discount. The latter study showed that these factors explain, on average, 35 percent of the month-to-month changes in the discount of U.K. closed-end funds.

A look toward the future. In reviewing the literature on closed-end funds, we have become aware of an ever-growing body of research, and we 
are confident that, for several reasons, a continuing flow of papers will supplement the articles surveyed here. First, the closed-end fund industry has shown itself to be creative and responsive to new circumstances; it has followed each industry downturn with a series of successful product launches. An initial offering at a premium has, of course, preceded every fund that trades at a discount, and we have no reason to suppose that the opportunity to float additional funds will disappear. So, closed-end funds are intriguing in their own right as an important part of the investment landscape.

Second, the closed-end fund industry provides an ideal opportunity to investigate specific issues in finance. In the U.S. market, for example, the governance of closed-end funds, as of other businesses, has come under scrutiny, and closed-end funds offer a setting for research into alternative organizational structures. Another opportunity for research is represented by innovations in the industry, such as U.K. split-capital funds, which have come under fire for lack of transparency and potential "misselling." Another research opportunity is provided by the transformation of many European mutual funds into open-ended investment companies whose shares can be traded but that sell at NAV because their share capital is no longer fixed. Every crisis and every innovation adds to the research agenda.

Finally, the closed-end fund discount provides one of the premier opportunities for examining a fundamental principle of economics: the Law of One Price. Much of finance presumes that economic values are additive. For instance, corporate finance textbooks assert that conglomerates (after adjusting for agency and other costs) are worth the sum of their parts, but the literature reveals that discounts to asset value are pervasive, notably among closed-end funds. Investment management textbooks invariably presume that portfolios are worth the sum of their holdings, but the literature indicates that closed-end fund portfolios are rarely worth their asset values. To investigate the validity of the Law of One Price, researchers need a laboratory, and the market for closed-end funds is that laboratory.

Although we certainly hope this monograph contributes to improved understanding of the closed-end fund discount, we also hope that it highlights a need for continuing research. A priority at this time is to extend our understanding of the discount. On the one hand, we need better economic theories of the discount. On the other hand, behavioral research is moving from ad hoc explanations based on irrational behavior to internally consistent models of limited rationality; increasingly, the focus is on the impact of market imperfections that inhibit arbitrage. The future lies in bringing together the economic and behavioral strands of research so as to unify our understanding of the closed-end fund discount. 


\section{References}

Abraham, Abraham, Don Elan, and Alan J. Marcus. 1993. "Does Sentiment Explain Closed-End Fund Discounts? Evidence from Bond Funds." Financial Review, vol. 28, no. 4 (November):607-616.

Adams, Andrew. 2000. "Excess Volatility and Investment Trusts." Working paper, University of Edinburgh.

AITC. 2001. Monthly Information Service. London: Association of Investment Trust Companies.

Ammer, John. 1990. "Expenses, Yields, and Excess Returns: New Evidence on Closed-End Fund Discounts from the U.K." Financial Markets Group Discussion Paper No. 108, London School of Economics.

Anderson, Seth. 1984. "Relationship between Value of an Investment Company's Shares and Value of the Underlying Net Assets." Ph.D. dissertation, University of North Carolina at Chapel Hill.

- 1986. "Closed-End Funds versus Market Efficiency." Journal of Portfolio Management, vol. 13, no. 1 (Fall):63-67.

Anderson, Seth, and Jeffery Born. 1992. "Closed-End Investment Companies: Issues and Answers." In Innovations in Financial Markets and Institutions, Volume 7. Boston, MA: Kluwer Academic Publishers.

Arnaud, A.A. 1983. Investment Trusts Explained. Cambridge, U.K.: Woodhead Faulkner.

Arora, Navneet, and Hui Ou-Yang. 2002. "Closed-End Funds: A Dynamic Model of Premiums and Discounts." Working paper, University of North Carolina.

AUTIF. 2001. “U.K. Funds under Management.” London: Association of Unit Trusts and Investment Funds.

Bailey, Warren, and Joseph Lim. 1992. "Evaluating the Diversification Benefits of the New Country Funds." Journal of Portfolio Management, vol. 18, no. 3 (Spring):74-80.

Bailey, Warren, Kalok Chan, and Y. Peter Chung. 2000. "Depositary Receipts, Country Funds, and the Peso Crash: The Intraday Evidence." Journal of Finance, vol. 55, no. 55 (December):2693-2717.

Bal, Y., and L.A. Leger. 1996. "The Performance of U.K. Investment Trusts." Service Industries Journal, vol. 16, no. 1 (January):67-81. 
Bangassa, Kenbata. 2000. "Performance of the U.K. Investment Trust IPOs." Working paper, University of Liverpool, U.K.

Barber, Brad. 1994. "Noise Trading and Prime and Score Premiums.” Journal of Empirical Finance, vol. 1, nos. 3-4 (July):251-278.

Barclay, Michael, Clifford Holderness, and Jeffrey Pontiff. 1993. "Private Benefits from Block Ownership and Discounts on Closed-End Funds.” Journal of Financial Economics, vol. 33, no. 3 (June):263-291.

Funds." Journal of Applied Corporate Finance, vol. 8, no. 1 (Spring):32-42.

Barclay, Michael, Neil Pearson, and Michael Weisbach. 1998. "Open-End Mutual Funds and Capital-Gains Taxes.” Journal of Financial Economics, vol. 49, no. 1 (July):3-43.

Baur, M., P. Coelho, and G. Santoni. 1996. "Management Expenses and the Closed-End Fund Puzzle.” Journal of Economics, vol. 22, no. 1 (Spring):37-46.

Bekaert, Geert, and Michael Urias. 1996. "Diversification, Integration and Emerging Market Closed-End Funds.” Journal of Finance, vol. 51, no. 3 (July):835-869.

Bers, Martina, and Jeff Madura. 2000. "The Performance Persistence of Closed-End Funds.” Financial Review, vol. 35, no. 3 (August):33-52.

Bhattacharyya, Sugato, and Vikram Nanda. 1999. "Marking to Market and the Closed-End Fund Discount.”Working paper, University of Michigan Business School.

Bleaney, Michael. 2002. "Investor Sentiment and Discounts on Closed-End Funds.” Working paper, School of Economics, University of Nottingham.

Bodurtha, James, Dong-Soon Kim, and Charles Lee. 1995. "Closed-End Country Funds and U.S. Market Sentiment.” Review of Financial Studies, vol. 8, no. 3 (Fall):879-918.

Bonser-Neal, Catherine, Greggory Brauer, Robert Neal, and Simon Wheatley. 1990. "International Investment Restrictions and Closed-End Country Fund Prices.” Journal of Finance, vol. 45, no. 2 (June):523-547.

Boudreaux, Kenneth. 1973. "Discounts and Premiums on Closed-End Funds: A Study in Valuation.” Journal of Finance, vol. 28, no. 2 (May):515-522.

Brauer, Greggory. 1984. “'Open-Ending’ Closed-End Funds.” Journal of Financial Economics, vol. 13, no. 4 (December):491-507. 
- 1988. "Closed-End Fund Shares' Abnormal Returns and the Information Content of Discounts and Premiums.” Journal of Finance, vol. 43, no. 1 (March):113-127.

Brauer, Greggory, and Eric Chang. 1990. "Return Seasonality in Stocks and Their Underlying Assets: Tax-Loss Selling versus Information Explanations.” Review of Financial Studies, vol. 3, no. 2 (Summer):255-280.

Brickley, James, and James Schallheim. 1985. "Lifting the Lid on Closed-End Investment Companies: A Case of Abnormal Returns.” Journal of Financial and Quantitative Analysis, vol. 20, no. 1 (March):107-117.

Brickley, James, Steven Manaster, and James Schallheim. 1991. "The TaxTiming Option and the Discounts on Closed-End Investment Companies." Journal of Business, vol. 64, no. 3 (July):287-312.

Brown, Christopher. 1998. Discounts: Theory \& Evidence. London: Cazenove.

Burch, Timothy, and Kathleen Weiss Hanley. 1996. "When Are Closed-End Funds Open? Rights Offers as a Response to Premiums.” Working paper, University of Maryland.

Cakici, Nusret, Anthony Tessitore, and Nilufer Usmen. 2000. "Closed-End Equity Funds: Betting on Discounts and Premiums.” Journal of Investing, vol. 3, no. 4 (Winter):83-92.

- 2002. "Closed-End Funds and Turnover Restrictions.” Financial Analysts Journal, vol. 58, no. 3 (May/June):74-81.

Cao, X.Q., and M. Esman. 2002. "Evaluating the Performance of Chinese Investment Funds." Working paper, University of Twente, Netherlands.

Cardell, Daniel, and James Miller. 1994. "Is Style Management Out of Style?” Journal of Applied Corporate Finance, vol. 6, no. 4 (Winter):93-97.

Chang, Eric, Cheol Eun, and Richard Kolodny. 1995. "International Diversification through Closed-End Country Funds.” Journal of Banking and Finance, vol. 19, no. 7 (October):1237-63.

Chay, Jong-Bom. 1992. "The Pricing of Closed-End Funds: Discounts and Managerial Performance.” Ph.D. dissertation, State University of New York at Buffalo.

Chay, Jong-Bom, and Charles Trzcinka. 1999. "Managerial Performance and the Cross-Sectional Pricing of Closed-End Funds.” Journal of Financial Economics, vol. 52, no. 3 (June):379-408. 
Chen, Gongmeng, Oliver Rui, and Yexiao Xu. 2002. "A First Look at ClosedEnd Funds in China.” Working paper, University of Texas at Dallas.

Chen, Hsiu-Lang, Narasimhan Jegadeesh, and Russ Wermers. 2000. “The Value of Active Mutual Fund Management: An Examination of the Stockholdings and Trades of Fund Managers." Journal of Financial and Quantitative Analysis, vol. 35, no. 3 (September):343-368.

Chen, Joseph, Harrison Hong, and Jeremy Stein. 2002. "Breadth of Ownership and Stock Returns.” Journal of Financial Economics, vol. 66, nos. 2-3 (November).

Chen, Nai-Fu, Raymond Kan, and Merton Miller. 1993. "Are the Discounts on Closed-End Funds a Sentiment Index?” Journal of Finance, vol. 48, no. 2 (June):795-800.

Chen, Nai-Fu, Richard Roll, and Stephen Ross. 1986. "Economic Forces and the Stock Market.” Journal of Business, vol. 59, no. 3 (July):383-403.

Cheng, A., Laurence Copeland, and John O'Hanlon. 1994. "Investment Trust Discounts and Abnormal Returns: U.K. Evidence." Journal of Business Finance and Accounting, vol. 21, no. 6 (September):813-831.

Choi, Jongmoo Jay, and Insup Lee. 1996. "Market Segmentation and the Valuation of Closed-End Country Funds: An Empirical Analysis.” Review of Quantitative Finance and Accounting, vol. 7, no. 1 (July):45-63.

Chopra, Navin, Charles Lee, Andrei Shleifer, and Richard Thaler. 1993. "Yes, Discounts on Closed-End Funds Are a Sentiment Index." Journal of Finance, vol. 48, no. 2 (June):801-808.

Clarke, Jonathan, and Kuldeep Shastri. Forthcoming 2003. “Adverse Selection Costs and Closed-End Funds." Journal of Financial and Quantitative Analysis.

CLL. 2001. Investment Trust Yearbook. London: Crédit Lyonnais Laing.

Coles, Jeffrey, Jose Suay, and Denise Woodbury. 2000. "Fund Advisor Compensation in Closed-End Funds.” Journal of Finance, vol. 55, no. 3 (June):1385-1414.

Constantinides, George. 1983. "Capital Market Equilibrium with Personal Tax.” Econometrica, vol. 51, no. 3 (May):611-636.

1984. "Optimal Stock Trading with Personal Taxes: Implications for Prices and the Abnormal January Returns.” Journal of Financial Economics, vol. 13, no. 1 (March):65-90. 
Cooper, Ian, and Evi Kaplanis. 1994. "Home Bias in Equity Portfolios, Inflation Hedging and International Capital Market Equilibrium.” Review of Financial Studies, vol. 7, no. 1 (Spring):45-60.

Cuny, Charles. 1997. "Mutual Funds, Taxes, and Fund Inflows.” Working paper, London Business School.

Dann, Larry, Diane Del Guercio, and Megan Partch. Forthcoming 2003. "Governance and Boards of Directors in Closed-End Investment Companies." Journal of Financial Economics.

Datar, Vinay, and David Dubofsky. 1999. "The Reaction of Closed-End Funds to Stock Distribution Announcements.” Financial Review, vol. 34, no. 2 (May):73-88.

Datar, Vinay, Narayan Naik, and Robert Radcliffe. 1998. "Liquidity and Stock Returns: An Alternative Test.” Journal of Financial Markets, vol. 1, no. 2 (August):203-219.

Deaves, Richard, and Itzhak Krinsky. 1994. "A Possible Reconciliation of Some of the Conflicting Findings on Closed-End Fund Discounts: A Note.” Journal of Business Finance and Accounting, vol. 21, no. 4 (October):1047-57.

Deli, Daniel, and Raj Varma. 2002. "Closed-End versus Open-End:The Choice of Organizational Form.” Journal of Corporate Finance, vol. 8, no. 1 (January):1-27.

De Long, Bradford, and Andrei Shleifer. 1992. "Closed-End Fund Discounts.” Journal of Portfolio Management, vol. 18, no. 2 (Winter):46-53.

De Long, Bradford, Andrei Shleifer, Lawrence Summers, and Robert Waldmann. 1990. "Noise Trader Risk in Financial Markets.” Journal of Political Economy, vol. 98, no. 4 (August):703-738.

Dimson, Elroy. 1988. Stock Market Anomalies. New York: Cambridge University Press.

Dimson, Elroy, and Bernd Hanke. 2002. “The Expected Illiquidity Premium.” Working paper, London Business School.

Dimson, Elroy, and Paul Marsh, eds. 2001. Risk Measurement Service. London Business School.

Dimson, Elroy, and Carolina Minio-Kozerski. 1999. "Closed-End Funds: A Survey.” Financial Markets, Institutions and Instruments, vol. 8, no. 2 (May):1-41. 
Dimson, Elroy, and Carolina Minio-Paluello. 2001. "The Closed-End Fund Discount and Performance Persistence.” Working paper, London Business School.

—. 2002. "A Factor Model of the Closed-End Fund Discount.” Working paper, London Business School.

Dimson, Elroy, and Massoud Mussavian. 1998. "A Brief History of Market Efficiency.” European Financial Management, vol. 4, no. 1 (March):91-103.

1999. "Three Centuries of Asset Pricing." Journal of Banking and Finance, vol. 23, no. 12 (December):1745-69.

Dimson, Elroy, and Eli Talmor. 2003. "A History of Corporate Finance.” Working paper, London Business School.

Dimson, Elroy, Paul Marsh, and Mike Staunton. 2002. Triumph of the Optimists: 101 Years of Global Investment Returns. Princeton, NJ: Princeton University Press.

Draper, Paul. 1989. The Investment Trust Industry in the U.K.: An Empirical Analysis. Hampshire, U.K.: Gower.

Elton, Edwin, Martin Gruber, and Christopher Blake. 1996. "The Persistence of Risk-Adjusted Mutual Fund Performance.” Journal of Business, vol. 69, no. 2 (April):133-157.

Elton, Edwin, Martin Gruber, and Jeffrey Busse. 1998. "Do Investors Care about Sentiment?” Journal of Business, vol. 71, no. 4 (October):477-500.

Elton, Edwin, Martin Gruber, Sanjiv Das, and Matt Hlavka. 1993. "Efficiency with Costly Information: A Re-Interpretation of Evidence from Managed Portfolios." Review of Financial Studies, vol. 6, no. 1 (Spring):1-21.

Errunza, Vihang, Lemma Senbet, and Ked Hogan. 1998. "The Pricing of Country Funds from Emerging Markets: Theory and Evidence.” International Journal of Theoretical and Applied Finance, vol. 1, no. 1 (January):111-143.

Fama, Eugene, and Kenneth French. 1992. "The Cross-Section of Expected Stock Returns.” Journal of Finance, vol. 47, no. 2 (June):427-465.

1998. "Value versus Growth: The International Evidence." Journal of Finance, vol. 53, no. 6 (December):1975-99.

Ferguson, Robert, and Dean Leistikow. 2001. "Valuing Active Managers, Fees, and Fund Discounts." Financial Analysts Journal, vol. 57, no. 3 (May/ June):52-62. 
Fraser, P., and D.M. Power. 1992. "Predictability, Trends, and Seasonalities: An Empirical Analysis of U.K. Investment Trust Portfolios, 1970-1989.” Applied Financial Economics, vol. 2, no. 3 (March):161-171.

Fredman, Albert, and George Cole Scott. 1991. Investing in Closed-End Funds: Finding Value and Building Wealth. New York: New York Institute of Finance.

Fung, William, and David Hsieh. 1997. "Empirical Characteristics of Dynamic Trading Strategies: The Case of Hedge Funds.” Review of Financial Studies, vol. 10, no. 2 (Summer):275-302.

Gemmill, Gordon. 2001. "Capital Structure and Firm Value: A Study of SplitCapital Closed-End Funds in the UK." Working paper, City University Business School, London.

Gemmill, Gordon, and Dylan Thomas. 2002. "Noise-Trading, Costly Arbitrage, and Asset Prices: Evidence from Closed-End Funds." Journal of Finance, vol. 57, no. 6 (December):2571-94.

Grinblatt, Mark, and Sheridan Titman. 1992. "The Persistence of Mutual Fund Performance.” Journal of Finance, vol. 47, no. 5 (December):1977-84.

Grossman, Sanford, and Oliver Hart. 1980. "Takeover Bids, the Free-Rider Problem, and the Theory of the Corporation." Bell Journal of Economics and Management Science, vol. 11, no. 1 (Spring):42-64.

Gruber, Martin. 1996. "Another Puzzle: The Growth in Actively Managed Mutual Funds.” Journal of Finance, vol. 51, no. 3 (July):783-810.

Grullon, Gustavo, and Albert Wang. 2001. "Closed-End Fund Discounts with Informed Ownership Differential.” Journal of Financial Intermediation, vol. 10, no. 2 (April):171-205.

Guy, James. 1978. "The Performance of the British Investment Trust Industry.” Journal of Finance, vol. 33, no. 2 (May):443-455.

Hardouvelis, Gikas, Rafael La Porta, and Thierry Wizman. 1994. "What Moves the Discount on Country Equity Funds?” In The Internationalization of Equity Markets. Edited by Jeffrey Frankel. Chicago, IL: University of Chicago Press.

Higgins, Eric, Shawn Howton, and Shelly Howton. Forthcoming 2003. "An Analysis of Closed-End Seasoned Equity Offerings.” Journal of Financial Research.

Huberman, Gur. 2001. "Familiarity Breeds Investment.” Review of Financial Studies, vol. 14, no. 3 (Fall):659-680. 
ICI. 2002. Mutual Funds: Facts \& Figures. Washington, DC: Investment Company Institute.

Jensen, Michael, and William Meckling. 1976. "Theory of the Firm: Managerial Behavior, Agency Costs and Capital Structure.” Journal of Financial Economics, vol. 3, no. 7 (October):305-360.

Jones, Charles, and Owen Lamont. 2002. "Short Sale Constraints and Stock Returns.” Journal of Financial Economics, vol. 66, nos. 2-3 (November):207239.

Keim, Donald, and William Ziemba. 2000. Security Market Imperfections in World Wide Equity Markets. New York: Cambridge University Press.

Kellerhals, Philipp, and Rainer Schöbel. 2002. "The Dynamic Behavior of Closed-End Funds and Its Implication for Pricing, Forecasting, and Trading." Journal of Banking and Finance, vol. 26, no. 8 (August):1615-43.

Khorana, Ajay, Sunil Wahal, and Marc Zenner. 2002. "Agency Conflicts in Closed-End Funds: The Case of Rights Offerings." Journal of Financial and Quantitative Research, vol. 37, no. 2 (June):177-200.

Khurshed, Arif, and Ram Mudambi. 2001. "The Short-Run Price Performance of Investment Trust IPOs on the U.K. Main Market.” Applied Financial Economics, vol. 12, no. 4 (October):697-706.

Kim, Chang-Soo. 1994. "Investor Tax-Trading Opportunities and Discounts on Closed-End Mutual Funds.” Journal of Financial Research, vol. 17, no. 1 (Spring):65-75.

Klibanoff, Peter, Owen Lamont, and Thierry Wizman. 1998. "Investor Reaction to Salient News in Closed-End Country Funds." Journal of Finance, vol. 53, no. 2 (April):673-699.

Kraakman, R. 1988. "Taking Discounts Seriously: The Implications of 'Discounted' Share Prices as an Acquisition Motive.” Columbia Law Review, vol. 88, no. 5 (June):891-941.

Kraft, Arthur, and Ira Weiss. 2001. "Tax Planning by Mutual Funds: Evidence from Changes in the Capital Gains Tax Rate.” Working paper, London Business School.

Kramer, Charles, and Todd Smith. 1998. "The Mexican Crisis and the Behavior of Country-Fund Discounts: Renewing the Puzzle of Closed-End Fund Pricing." International Journal of Theoretical and Applied Finance, vol. 1, no. 1 (January):61-174. 
Kumar, Raman, and Gregory Noronha. 1992. "A Re-Examination of the Relationship between Closed-End Fund Discounts and Expenses.” Journal of Financial Research, vol. 15, no. 2 (Summer):139-147.

Lakonishok, Josef, Andrei Shleifer, and Robert Vishny. 1992. "The Impact of Institutional Trading on Stock Prices." Journal of Financial Economics, vol. 32, no. 1 (August):23-43.

Lamont, Owen, and Richard Thaler. Forthcoming 2003. "Can the Market Add and Subtract? Mispricing in Tech Stock Carve-Outs.” Journal of Political Economy.

Lee, Charles, Andrei Shleifer, and Richard Thaler. 1990. "Anomalies: Closed-End Mutual Funds.” Journal of Economic Perspectives, vol. 4, no. 4 (Fall):153-164.

1991. "Investor Sentiment and the Closed-End Fund Puzzle.” Journal of Finance, vol. 46, no. 1 (March):76-110.

Leger, L.A. 1997. "U.K. Investment Trusts: Performance, Timing, and Selectivity.” Applied Economics Letters, vol. 4, no. 4 (April):207-210.

Levis, Mario, and Dylan Thomas. 1995. "Investment Trust IPOs: Issuing Behavior and Price Performance. Evidence from the London Stock Exchange." Journal of Banking and Finance, vol. 19, no. 8 (November):1437-58.

-. 2000. "Country Funds and Investor Sentiment: U.K. and U.S. Evidence.” Working paper, City University Business School.

Levy-Yeyati, Eduardo, and Angel Ubide. 2000. "Crises, Contagion, and the Closed-End Country Fund Puzzle.” International Monetary Fund Staff Papers, vol. 47, no. 1 (November):1-54.

Lofthouse, Stephen. 1999. "Closed-End Fund and Investment Trust Discounts.” Journal of Investing, vol. 8, no. 1 (Spring):27-37.

Malkiel, Burton. 1977. "The Valuation of Closed-End Investment-Company Shares.” Journal of Finance, vol. 32, no. 3 (June):847-858.

Malkiel, Burton, and Paul Firstenberg. 1978. "A Winning Strategy for an Efficient Market.” Journal of Portfolio Management, vol. 4, no. 4 (Summer):20-25.

McConnell, John, and Henri Servaes. 1990. "Additional Evidence on Equity Ownership and Corporate Value.” Journal of Financial Economics, vol. 27, no. 2 (October):595-612. 
Merton, Robert. 1973. "Theory of Rational Option Pricing." Bell Journal of Economic and Management Science, vol. 4, no. 1 (Spring):141-183.

Minio-Paluello, Carolina. 1998. “The U.K. Closed-End Fund Discount.” Ph.D. dissertation, London Business School.

Morck, Randall, Andrei Shleifer, and Robert Vishny. 1988. "Management Ownership and Market Valuation.” Journal of Financial Economics, vol. 20, no. 2 (March):293-315.

Morey, Matthew. Forthcoming 2003. "Should You Carry the Load? A Comprehensive Analysis of Load and No-Load Mutual Fund Out-of-Sample Performance.” Journal of Banking and Finance.

Neal, Robert, and Simon Wheatley. 1998a. "Adverse Selection and Bid-Ask Spreads: Evidence from Closed-End Funds.” Journal of Financial Markets, vol. 1, no. 1 (February):121-149.

1998b. “Do Measures of Investor Sentiment Predict Returns?” Journal of Financial and Quantitative Analysis, vol. 33, no. 4 (December):523-547.

Newlands, John. 1997. Put Not Your Trust in Money: A History of the Investment Trust Industry from 1868 to the Present Day. London: Chappin Kavanagh.

Nishiotis, George. 1999. "A Measure of Capital Market Integration Based on Closed-End Country Fund Prices and International Capital Flows.” Working paper, Tulane University.

Patro, Dilip Kumar. 2001. "Measuring Performance of Closed-End International Mutual Funds.” Journal of Banking and Finance, vol. 25, no. 9 (September):1741-67.

Peavy, John. 1990. "Returns on Initial Public Offerings of Closed-End Funds." Review of Financial Studies, vol. 3, no. 4 (Winter):695-708.

Pontiff, Jeffrey. 1995. "Closed-End Fund Premiums and Returns: Implications for Financial Market Equilibrium.” Journal of Financial Economics, vol. 37, no. 3 (March):341-367.

—. 1996. “Costly Arbitrage: Evidence from Closed-End Funds.” Quarterly Journal of Economics, vol. 111, no. 4 (November):1135-51.

1997. "Excess Volatility and Closed-End Funds." American Economic Review, vol. 87, no. 1 (March):155-169. 
Porter, Gary, Rodney Roenfeldt, and Neil Sicherman. 1999. "The Value of Open Market Repurchases of Closed-End Fund Shares.” Journal of Business, vol. 72 , no. 2 (April):257-276.

Pratt, Eugene. 1966. "Myths Associated with Closed-End Investment Company Discounts.” Financial Analysts Journal, vol. 22, no. 4 (July/August):79-82.

Rock, Kevin. 1986. "Why New Issues Are Under-Priced.” Journal of Financial Economics, vol. 15, no. 1 (January):187-212.

Roenfeldt, Rodney, and Donald Tuttle. 1973. "An Examination of the Discounts and Premiums of Closed-End Investment Companies.” Journal of Business Research, vol. 1, no. 2 (Fall):129-140.

Ross, Stephen. 2002. "Neoclassical Finance, Alternative Finance and the Closed-End Fund Puzzle.” European Financial Management, vol. 8, no. 2 (June):129-137.

Rozeff, Michael. 1991. “Closed-End Fund Discounts and Premiums.” In Pacific Basin Capital Markets Research: Volume II. Edited by S. Ghon Rhee and Rosita Chang. Amsterdam: North-Holland.

Schwert, William. 1989. "Why Does Stock Market Volatility Change over Time?” Journal of Finance, vol. 44, no. 5 (December):1115-53.

Seltzer, David Fred. 1989. "Closed-End Funds: Discounts, Premiums, and Performance.” Ph.D. dissertation, University of Arizona.

Seyhun, Nejat, and Douglas Skinner. 1994. "How Do Taxes Affect Investors' Stock Market Realizations? Evidence from Tax-Return Panel Data.” Journal of Business, vol. 67, no. 2 (April):231-262.

Sharpe, William. 1992. "Asset Allocation: Management Style and Performance Measurement.” Journal of Portfolio Management, vol. 18, no. 2 (Winter):7-19.

Shleifer, Andrei, and Robert Vishny. 1997. "The Limits of Arbitrage.” Journal of Finance, vol. 52, no. 1 (March):35-55.

Sias, Richard. 1997. "The Sensitivity of Individual and Institutional Investors' Expectations to Changing Market Conditions: Evidence from Closed-End Funds.” Review of Quantitative Finance and Accounting, vol. 8, no. 3 (May):245-269.

Sias, Richard, Laura Starks, and Seha Tinic. 2001. "Is Noise Trader Risk Priced?” Journal of Financial Research, vol. 24, no. 3:311-329. 
Spiegel, Matthew. 1999. "Closed-End Fund Discounts in a Rational Agent Economy.” Working paper, Yale School of Management.

Swaminathan, Bhaskaran. 1994. "A Rational Model of Closed-End Fund Discounts.” Working paper, University of California at Los Angeles.

1996. "Time-Varying Expected Small Firm Returns and Closed-End Fund Discounts.” Review of Financial Studies, vol. 9, no. 3 (Fall):845-887.

Thompson, Rex. 1978. "The Information Content of Discounts and Premiums on Closed-End Fund Shares.” Journal of Financial Economics, vol. 6, nos. 2/3 (June-September):151-186.

Warburg Securities. 1988-1990. "Investment Trust Manual.” SG Warburg Securities Ltd.

Weiss, Kathleen. 1989. "The Post-Offering Price Performance of Closed-End Funds.” Financial Management, vol. 18, no. 3 (Autumn):57-67.

Weiss Hanley, Kathleen, and Nejat Seyhun. 1994. "The Profitability of Short Selling: Evidence from Closed-End Funds." Working paper, University of Michigan.

Weiss Hanley, Kathleen, Charles Lee, and Paul Seguin. 1996. "The Marketing of Closed-End Fund IPOs: Evidence from Transactions Data." Journal of Financial Intermediation, vol. 5, no. 2 (April):127-159.

Whiting, A. 1984. "The Analysis of the Share Discounts of U.K. Investment Trust Companies: A Time Series Approach.” Ph.D. dissertation, University of Lancaster.

Wu, Matthew Qianli, and Yihong Xia. 2001a. "Co-Movement and Information Content of Closed-End Fund Discounts." Working paper, The Wharton School, University of Pennsylvania.

_. 2001b. "Liquidity Risk and the Closed-End Fund Discount: A Rational Explanation.”Working paper, The Wharton School, University of Pennsylvania.

Zheng, Lu. 1999. "Is Money Smart? A Study of Mutual Fund Investors' Fund Selection Ability.” Journal of Finance, vol. 54, no. 3 (June):901-933.

Zweig, Martin. 1973. “An Investor Expectations Stock Price Predictive Model Using Closed-End Fund Premiums.” Journal of Finance, vol. 28, no. 1 (March):67-78. 